\title{
BOSNA I HERCEGOVINA IZMEĐU REGIONALNE I SVJETSKE ANTROPOLOGIJE KAO TALAC ETATISTIČKO-BIROKRATSKE PROCEDURALNOSTI
}

\author{
Indira Kučuk-Sorguč \\ JU Muzej Sarajeva \\ ikucuksorguc@gmail.com
}

\begin{abstract}
Apstrakt: Ovaj se rad bavi historijatom i suvremenim razvojem antropologije u Bosni i Hercegovini i jugoistočnoj Evropi, odgovarajući na pitanje zbog čega na bosanskohercegovačkim univerzitetima nikada nije ustanovljen studij antropologije. Naglasak je na odgovorima koji su dobijeni od priznatih univerzitetskih profesora, doktora etnologije, bioantropologije i socijalne antropologije koji su kroz svoj dugogodišnji profesorski i znanstvenoistraživački rad, ali i društveni aktivizam iskazali potrebu za otvaranjem ovog studija u Bosni i Hercegovini. Zašto zemlja koja je bremenita kulturnohistorijskim naslijeđem i tangentna je tačka na mapi Balkana kao sinonim multietnicizma, multikulturalizma i multikonfesionalizma, čija je differentia specifica izložena u tim signifikantnim društvenoantropološkim obrascima na kojima se i temelji ova sveobuhvatna holistička znanost o čovjeku, nije spremna za studij antropologije? Bosna i Hercegovina se u postkonfliktnoj epohi otvorila kao atraktivna destinacija za svjetske antropologe; apsurd leži u činjenici da pogledu "izvana” treba pridružiti i stručni pogled "iznutra”. Da li će senati rektorata svih univerziteta u Bosni i Hercegovini, koji nadasve djeluju kao društveno-političke organizacije, konačno pokrenuti inicijativu za uspostavljanje studija etnologije i antropologije ili će kao do sada Bosna i Hercegovina služiti kao "vječna moneta za potkusurivanje" nekih davno nereguliranih političkih (multi)etničkih cehova?
\end{abstract}

Ključne riječi: kultura, Bosna i Hercegovina, čovjek, antropologija, etnologija, jugoistočna Evropa, odsjek, studij 


\begin{abstract}
This paper deals with the history and contemporary development of anthropology in Bosnia and Herzegovina and Southeast Europe with particular emphasis on its (non) existence at university departments in Bosnia and Herzegovina. The emphasis is also on answers and feedback received from renowned university professors, namely Ethnology and Social Anthropology $\mathrm{PhD}$. experts who, through the many years of professorial and scientific research and social activism, have expressed and communicated the need for Anthropology studies establishing and opening in Bosnia and Herzegovina. Why is it that this country, gravid with cultural and historical heritage, being furthermore a tangent point on the map of the Balkans as a synonym for multi-ethnic, multicultural and multiconfessional existence, the country whose differentia specifica is exposed in these significant socio-anthropological patterns that are also the base for this comprehensive holistic science on humans, is not ready for the Anthropology studies? In the post-conflict era, Bosnia and Herzegovina opened as an attractive destination for world anthropologists; the absurdity lies in the fact that the "outside" view should be accompanied by the "inside" expert view. Will the senates of the rectories of all universities in $\mathrm{BiH}$, acting as socio-political organizations, finally launch an initiative to establish Ethnology and Anthropological Studies, or will Bosnia and Herzegovina serve as the "eternal coin for servicing" of some long unregulated political (multi) ethnic reckonings and/or accounts?
\end{abstract}

Keywords: culture, Bosnia and Herzegovina, humanity, anthropology, ethnology, Southeast Europe, department, study

Zemlje jugoistočne Evrope (u poslijesocijalističkom dobu samostalne suverene države) Slovenija, Hrvatska, Srbija, Crna Gora i Sjeverna Makedonija, u različitim vremenskim periodima i pod različitim sociokulturnim uvjetima su kroz naučni aparat provele izučavanje etnoloških obrazaca kao simbola za razumijevanje vlastitog etnosa i nacionalnog bića. Srbija i Hrvatska su svoj susret sa antropološkom naukom imale još početkom 20. stoljeća, a fundamentalni okvir za njeno izučavanje formiran je u periodu SFRJ. ${ }^{1}$ Studiji antropologije postoje danas na univerzitetima u Ljubljani,

${ }^{1}$ Razvoj antropologije u Srbiji i Crnoj Gori (ovdje se Srbija i Crna Gora povezuju zajedno zbog njihovog zajedničkog državotvornog uređenja koja je kroz SRJ i Državnu zajednicu Srbija i Crna Gora trajala do juna 2006. godine, dok su u ranijim historijskim periodima u smislu proučavanja 


\section{Zagrebu, Beogradu i Skoplju. ${ }^{2}$}

U Srbiji je 2016. godine Odjeljenje za etnologiju i antropologiju obilježilo 135 godina od uvođenja etnologije u nastavu na Velikoj školi i 110 godina od osnivanja Etnološkog seminara na Filozofskom fakultetu. Ovo Odjeljenje se prvobitno zvalo Odjeljenje za etnologiju da bi 1990. dopunilo svoj naziv u Odjeljenje za etnologiju i antropologiju, administrativno obilježivši značajne teorijsko-metodološke promjene, koje su disciplinu iz tradicionalno orijentiranog proučavanja isključivo nacionalne kulture, transformirale u savremenu socio-kulturnu analizu društvene stvarnosti i

antropološke znanosti Podgorica i Beograd djelovali koordinirano) odvijao se u sličnim okolnostima i prošao je kroz tri veće etape. Prvi period, od sredine 19. do početka 20. vijeka, karakterizira stihijno sabiranje građe od ljudi drugih struka (geologija, geografija, arheologija, etnologija). U drugom razdoblju, od početka 20. vijeka do početka Drugog svjetskog rata, antropologija se razvija u okviru higijenske službe i u pojedine ustanove ulazi kao nauka o čovjeku. Na Univerzitetu u Beogradu predaje se od 1906. kao opća nauka o čovjeku uz pojedine predmete (antropogeografija, etnologija, biologija, pojedine medicinske nauke). Posvećuje se pažnja izučavanju morfologije čovjeka, njegovoj biotipologiji, ljudskim rasama i njihovim varijetetima. Treće razdoblje obuhvaća period poslije Drugog svjetskog rata. U ovom razdoblju, u odnosu na prethodne periode, antropologija se u Srbiji i Crnoj Gori institucionalizirala, proširila djelatnost i povezala se, posebno sa osnivanjem Antropološkog društva Jugoslavije (1959) sa međunarodnim antropološkim institucijama. Vidjeti više na: http://scindeks.ceon.rs/article.aspx?artid=1820-79361045017V U ovom periodu se svake godine kontinuirano održavaju antropološki naučni skupovi sa međunarodnim učešćem, konstituira se nastava antropologije u pojedinim univerzitetskim centrima, proširuje izdavačka djelatnost i razvijaju se sve oblasti antropoloških proučavanja. Četvrto razdoblje u razvoju antropoloških nauka u Srbiji i Crnoj Gori počinje od reorganizacije Antropološkog društva Jugoslavije na XXXI redovnom kongresu koji je održan krajem maja 1992. godine u Kotoru (Crna Gora) i završava se osnivanjem Antropološkog društva Srbije (30. maja 2007) na XLVI kongresu u Apatinu. U to vrijeme su se pojedine jugoslovenske republike osamostalile pa su i članovi zajedničkog Antropološkog društva, osim iz Srbije i Crne Gore, napustili ovu veoma uspješnu stručno-naučnu organizaciju.

${ }^{2}$ U Srbiji i Sloveniji etnologija sa etnografijom se izučava od osnivanja univerziteta u Beogradu i Ljubljani. Na Filozofskom fakultetu u Zagrebu samostalna Katedra za etnologiju i etnografiju osnovana je odlukom Ministarstva prosvjete od 27. 01. 1925. godine. Izvor: https//etno.ffyg. unizg.hr/odsjek/povijest-odsjeka/. Katedra pa Odsjek su od tada mijenjali ime. Danas Odsjek izvodi dva studija na preddiplomskoj i diplomskoj razini: Etnologija i kulturna antropologija i Antropologija, te jedini u Republici Hrvatskoj i doktorski studij Etnologije i kuturne antropologije. Poslijediplomski studij etnologije uveden je na Filozofskome fakultetu Sveučilišta u Zagrebu godine 1961. (Opširnije: https://etno.ffzg.unizg.hr/wp-content/uploads/2012/11/Doktorski-program-etnologije-i-kulturne-antropologije-za-web_4-4-2017.pdf. pristupljeno: 14. 06. 2019) 
kulturne raznovrsnosti na nacionalnom, regionalnom i globalnom nivou. ${ }^{3}$ Zbog specifične interdisciplinarne otvorenosti i unutardisciplinarne povezanosti antropologije sa drugim disciplinama, nastavnici, saradnici i istraživači sarađuju na temama kao što su kulturni identiteti, politička i kulturna tranzicija, materijalna i nematerijalna kulturna baština, multikulturalizam, globalizacija, novi religijski pokreti, i dr. Odjeljenje izdaje časopis Etnoantropološki problemi (www.anthroserbia.org) i suizdavač je Etnološke biblioteke (www.etnoloskabiblioteka.co.rs). ${ }^{4}$

U Hrvatskoj je prvo antropološko društvo osnovano 1924. godine kao Antropološka sekcija Sociološkoga društva. ${ }^{5}$ Prva samostalna antropološka znanstvena ustanova - Institut za antropologiju - osnovana je u Zagrebu 1992. godine. Od 1977. godine izlazi u Zagrebu znanstveni antropološki časopis Collegium Antropologicum (na engleskom jeziku) o kojem se referira u referentnim publikacijama Current Contents (CC), Social Science Citation Index (SSCI) i nizu drugih publikacija.

${ }^{3}$ Tek od sedamdesetih godina 20. vijeka, predmet antropologija se proučava u okviru Katedre za sociologiju Filozofskog fakulteta u Beogradu oslanjajući se na interepretacije marksizma. U okviru izučavanju etnologije do sedamdesetih godina su se proučavali problemi materijalne kulture, etničkih procesa, izučavanje običaja, vjerovanja i naslijeđa u kontekstu ruralne tradicijske kulture. Kasnije dolazi do postepene primjene antropoloških teorija, prije svega strukturalističkih i strukturalno-funkcionalističkih metoda na značajne društvene fenomene. Dalja primjena savremenih antropoloških tema kao što su urbana antropologija, politička antropologija, ekonomska antropologija, antropologija roda i srodstva, antropologija religije polako se etablirala u nastavni program Filozofskog fakulteta Univerziteta u Beogradu. Od 1990. godine, ova znanost se izučava pod nazivom etnologija-antropologija i pod njenim okriljem su se razvijali ogranci Instituta etnologije i antropologije. Antropološkim i etnološkim temama se bave i Etnografski muzej u Beogradu, Etnografski institut SANU, Balkanološki institut SANU, Etnološko-antropološko društvo Srbije, Institut društvenih nauka, itd.

${ }^{4}$ Glasnik Antropološkog društva Srbije, Beograd: ADS, 2009, broj 44, 17-25

${ }^{5}$ https://web2020.ffzg.unizg.hr/ (pristupljeno: 14. 6. 2019) Važna imena za razvoj antropologije početkom 20. stoljeća u Hrvatskoj su: D. Gorjanović-Kramberger, A. Weissbach, Đ. Pilar, B. Zarnik i drugi. H. Maver i P. Rudan 1974. pri Hrvatskome liječničkom zboru osnivaju Sekciju za biološku antropologiju (danas Hrvatsko društvo za medicinsku antropologiju), a 1977. Hrvatsko antropološko društvo. Europska udruga antropologa (European Anthropological Association) osnovana je u Zagrebu 1976. Prvi kongres antropologa Europe održan je u Zagrebu 1977. godine, dok je 1998. u Zagrebu osnovana Međunarodna udruga fizioloških antropologa. 
Prvi se put u Hrvatskoj antropologija mogla upisati kao dodiplomski univerzitetski studij akademske godine 2000/2001. Za izvedbu toga studija osnovana je 1998. godine na Filozofskom fakultetu Sveučilišta u Zagrebu posebna Fakultetska katedra za antropologiju, a prvi program Studija antropologije osmislili su prof. dr. sc. Vjekoslav Afrić, akademik Pavao Rudan, prof. dr. sc. Vitomir Belaj.

Etnologija ili kulturna antropologija u Sloveniji ima uzornu i dugu povijest. Seminar za etnografiju osmišljen je 1919. godine, kada je osnovan Univerzitet u Ljubljani, a uključen je u organizacijsku strukturu Filozofskog fakulteta. Redovito proučavanje "etnologije sa etnografijom" počelo je u akademskoj godini 1940/41. Kurs koji je osmislio prvi visokoškolski nastavnik etnologije/kulturne antropologije u Sloveniji prof. dr. Niko Zupanič bio je izuzetno antropološki. Katedru etnologije preuzeo je 1957. godine, dok je prvi doktorski studij etnologije u Sloveniji vodio prof. dr. Vilko Novak, koji je posebnu pažnju posvetio predstavljanju slavenske i slovenske narodne kulture, a osim predavanja o općoj etnologiji, Novak je sistematski prikazao etnologije Južnih Slavena i naroda Evrope. Terenski i terenski studiji važan su dio svih kolegija od samog početka studija etnologije (kulturne antropologije) na Univerzitetu u Ljubljani. ${ }^{6}$

Profesor Božo Škerlj sa Univerziteta u Ljubljani se može smatrati pokretačem antropologije u Sloveniji kao i u bivšoj zajedničkoj državi. On je jedan od osnivača katedre za antropologiju i pisac prvog udžbanika na južnoslavenskim jezicima (prijevod: “Opća antropologija u osnovnim potezima”), a Ljubljana je generalno u istraživanju ove struke išla u korak sa zapadnom antropologijom. Slijedeći veliki pomak dogodio se u akademskoj godini 1990/91, kada se u ime katedre izričito pojavila kulturna antropologija, a nedugo zatim, dvogodišnji preddiplomski studij uveden je u neovisni studij

\footnotetext{
${ }^{6}$ Istaknuti antropolozi u jugoistočnoj Evropi prof. dr. Vilko Novak i prof. dr. Slavko Kremenšek ustanovili su koncept terenskih seminara, tzv. "praznične vježbe" na kojima su sa studentima izučavali određene pojave kao da idu "na izlet”, i iz toga metodološki razvijali antropološke koncepte. Prof. dr. Slavko Kremenšek se, s jedne strane, odrekao uskog razumijevanja popularne kulture, koja se do tada bila povezivala samo sa seoskim dijelom i počeo proučavati radnu i urbanu kulturu, a s druge, oslanjao se na izrazito historističku metodološku paradigmu.
} 
etnologije i kulturne antropologije. Odjel za etnologiju i kulturnu antropologiju (OEKA) na Filozofskom fakultetu Univerziteta u Ljubljani je zbog svoje izuzetno bogate tradicije, istraživačkog iskustva i guste mreže međunarodnih veza, središnja etnološka i kulturna antropološka institucija u Sloveniji. ${ }^{7}$

U Sjevernoj Makedoniji na Univerzitetu sv. Ćiril i Metodije, na Prirodoslovno-matematičkom fakultetu djeluje Institut za etnologiju i antropologiju koji je nasljednik Odjeljenja za etnologiju i etnografiju formiranog 1946. godine. Institut je djelovao sa prekidima, a 1985/86. osnovan je i studij etnologije na Prirodoslovno-matematičkom fakultetu Skoplje da bi 2005. godine studij promijenio naziv u etnologija i antropologija, kao i Institut. ${ }^{8}$ Sjeverna Makedonija u proteklih deceniju progresivnim koracima napreduje na polju popularne antropologije posebno vizualne antropologije, koja pretendira da osjetilnim medijima daje primat $u$ istraživačkim procesima i kreira suvremene metodološke obrasce.

$\mathrm{Na}$ Univerzitetu Crne Gore u Podgorici antropologija se ne izučava kao samostalni studij, nego su predmet etnologija i sociokulturna antropologija kao i antropologija savremenosti i popularne kulture uspostavljeni u nastavnom planu i programu na studiju sociologije.

U Bosni i Hercegovina antropološka nauka nije još dobila svoj stabilni fundament u vidu univerzitetskog proučavanja kao zasebnog dodiplomskog studija ni u kategoriji društvenih kao ni humanističkih znanosti. Katedra za antropologiju nije egzistirala u Bosni i Hercegovini ni u vrijeme SFRJ, kada su studiji u Zagrebu i Beogradu, vjerovatno, prema tadašnjoj centraliziranoj nomenklaturi odlučivanja, predviđeni kao dostatni za osposobljavanje svih interesenata i mladih istraživača od "Vardara pa do Triglava”.

U periodu od 1945. do 1992. godine, u Bosni i Hercegovini obrasci antro-

\footnotetext{
7 Vidjeti: http://www.ff.uni-lj.si/1/Oddelki-in-studij/Oddelki/Oddelek-za-etnologijo-in-kulturnoantropologijo (pristupljeno: 11. 6. 2019)

${ }^{8}$ Vidjeti: http://www.pmf.ukim.edu.mk/c/portal/layout?p_l_id=PUB.1001.21 (pristupljeno: 14. 6. 2019) Naučno-nastavno vijeće Prirodoslovno-matematičkog fakulteta na Univerzitetu sv. Ćiril i Metodije u Skoplju izmijenio je Statut, pa je Zavodu za etnologiju promijenjeno ime u Institut za etnologiju i antropologiju. Također je i studij preimenovan u studij etnologije i antropologije.
} 
pološkog istraživanja i mišljenja su individualne prirode i prezentni su kod nekolicine znanstvenih istraživača etnološkog, etnografskog, arheološkog, povijesnog, lingvističkog, filozofskog i sociološkog spektra djelovanja. Još su rjeđi interdiciplinarni studiji opserviranja određene antropološke teme introspekcijskom metodologijom uz terenski rad i pogledom "izvana”. Ipak, može se reći da je Bosna i Hercegovina imala prvog magistra antropologije 1972. godine, koji je bio tada jedini magistar u bivšoj Jugoslaviji. Riječ je o akademiku prof. dr. Rifatu Hadžiselimoviću, koji je magistrirao na Sveučilištu u Zagrebu, a predavao je antropologiju na Prirodno-matematičkom fakultetu u Sarajevu.

Kulturna antropologija u Bosni i Hercegovini se razvija preko etnološkoetnografskih obrazaca i kroz institucije koje su u opisu svoga znanstvenog djelovanja očuvale tradiciju izučavanja i zastupanja etnologije. ${ }^{9}$ Razvitak ove univerzalne ljudske znanosti sa izraženim hermenautičkim parametrima, u Bosni i Hercegovini se naročito mogao iščitavati kroz kontinuirani rad etnologa Zemaljskog muzeja u Sarajevu još od osnivanja 1888. godine, a posebno od 1913. godine, kada je pri ovoj najvećoj i najstarijoj muzejsko-znanstvenoj instituciji u Bosni i Hercegovini i osnovan kao samostalno odjeljenje Etnološki odjel. ${ }^{10}$

\footnotetext{
${ }^{9}$ Prema sjevernoameričkoj i zapadnoevropskoj klasifikaciji "kulturna antropologija” u značenjskom smislu je ekvivalentna "etnologiji" u istočnoevropskoj i zapadnobalkanskoj znanstveno-istraživačkoj akademskoj praksi.

${ }^{10} \mathrm{O}$ tome: https://www.zemaljskimuzej.ba/bs/etnologija (pristupljeno: 14. 6. 2019)

Zemaljski muzej u Sarajevu je osnovan 1888. godine kao moderna kulturna i znanstvena institucija zapadnoga tipa u Bosni i Hercegovini. Neposredno nakon osnivanja, Odjeljenje za etnologiju je bilo integrirano s Odjeljenjem za arheologiju, ali se izdvojilo iz njega četiri godine kasnije. Od 1913. smješteno je u paviljonu Zemaljskog muzeja, čiji enterijer oslikava izgled bosanskohercegovačke tradicionalne gradske kuće. Prva stalna izložbena postavka bila je u zgradi Penzionog fonda, otvorena 1888. godine. Redale su se izložbe narodnih nošnji i učestvovanje na svjetskim izložbama u Beču, Zagrebu, Temišvaru, Budimpešti, Bruxellesu, Parisu, itd. Prva stalna izložbena postavka Etnografskog odjeljenja otvorena je 4. oktobra 1913. godne. U opisu postavke stoji slijedeće: "Na spratu su smještene originalne sobe, bogato rezbarene u drvetu, sa svim potrebnim inventarom, a u njima su izložene figure s narodnim nošnjama, raspoređene po geografskim oblasnim cjelinama. U jednoj su sobi bile smještene nošnje iz Albanije, Grčke i Bugarske. U prizemlju su u jednoj dvorani predstavljeni tekstilni predmeti, a u drugoj predmeti umjetničkih zanata od metala, drveta, keramike i kože."
} 


\section{Zemaljski muzej u Sarajevu je tako preuzeo od univerzitetskih institucija} pored uloge čuvara i zaštitnika građe, te istraživačkog i izdavačkog djelovanja i ulogu edukatora svojih kadrova, prezentirajući funkcije arheološkoga rada, skladištenja, teorijskog opisivanja terenskog etnografskog rada u Glasniku Zemaljskog muzeja, dajući tako mogućnost arheolozima i etnolozima da donesene materijalne dokaze i historijske činjenice o bogatoj historiji življenja domaćeg stanovništva u jednom vrlo pogodnom geografskom mjestu, kakav je prirodni prostor Bosne i Hercegovine, metodološki obrade i zabilježe.

"Iz djelatnosti Muzeja razvilo se nekoliko instituta koji su imali potencijal nastaviti i proširiti etnološki rad, uključujući Balkanološki institut ${ }^{11}$ i Institut za istraživanje folklora, koji je otvoren 1951, ali je prestao postojati već 1958. godine." 12

Balkanološki institut je osnovan još 1904. godine u okviru Zemaljskog muzeja, koji je djelovao sve do 1918. godine. ${ }^{13}$ Nakon dugogodišnje pauze,

${ }^{11}$ O razvoju "balkanologije" u Bosni i Hercegovini Blagoje Govedarica kaže: "Balkanološki institut koji je već 1904. godine vizionarski osnovao Karl Patsch bio je prva institucija te vrste na području jugoistočne Evrope. Mada nije bio dugoga vijeka, djelatnost tog instituta, a naročito kontinuirana aktivnost njegove matične organizacije, Zemaljskog muzeja, umnogome su doprinijeli da Sarajevo postane važno izvorište novih istraživačkih ideja i stremljenja. U tom kontekstu treba posmatrati i nastanak Centra za balkanološka ispitivanja u Akademiji nauka i umjetnosti BiH. Početak rada ove institucije, 1963. godine, bilo je velika inovacija u domenu balkanologije, ali do toga sasvim sigurno ne bi došlo da nije bilo dugog i vrijednog iskustva iz prethodnog perioda. Cjelovit pregled razvoja balkanologije u Sarajevu dat je u dvije edicije koje su izdate 1983. i 2013. godine povodom obilježavanja 20. i 50. godina Centra." Blagoje Govedarica, "Pedeset godina Centra za balkanološka ispitivanja Akademije nauka i umjetnosti Bosne i Hercegovine”, u: Međunarodna naučna konferencija "Balkanologija danas" u povodu 50-godišnjice Centra za balkanološka ispitivanja ANUBiH, Godišnjak, knjiga 42, Sarajevo: ANUBiH, 2013, 9.

${ }^{12}$ Larisa Kurtović, "Etnografski eksperimenti: Manifest za podršku razvoja društvenokulturne antropologije u Bosni i Hercegovini i kratak pregled studentskih radova", u: Godišnjak Fakulteta političkih nauka 5-6, Sarajevo: Falkultet političkih nauka, 2010/2011, 372.

Dostupno na: https://www.academia.edu/1457927/Etnografski_eksperimenti_Manifest_za_podršku_ razvoja_društvenokulturne_antropologije_u_Bosni_i_Hercegovini_i_kratak_pregled_studentskih_ radova (pristupljeno: 1. 8. 2019).

${ }^{13}$ Centar za balkanološka ispitivanja je jedno od prvih istraživačkih tijela osnovanih unutar Naučnog društva Bosne i Hercegovine (1963), te u okviru Akademije nauka i umjetnosti Bosne i Hercegovine (od 1966). Osnovni zadaci Centra su izučavanje jezika, života i kulture balkanskih naroda. Od 
pri Naučnom društvu Bosne i Hercegovine 1954. godine ponovno je osnovan Balkanološki institut, koji je okupljao saradnike više iz oblasti klasične filologije i lingvistike, te etnologije. Od 1957. godine Institut izdaje Godišnjak, redovni časopis koji je u svojih dosadašnjih 45 brojeva publicirao znanstvene radove eminentnih stručnjaka, koji su nastojali rasvijetliti i približiti prošlost ovih prostora naučnoj i široj javnosti. ${ }^{14}$ Zbog kadrovskih i organizacijskih teškoća, 1962. godine Institut se ukida, a umjesto njega se osniva Centar za balkanološka ispitivanja (1963). Ova institucija je doprinijela da se kroz konzistentna multidisciplinarna istraživanja sagledaju balkanski narodi, njihovi običaji i kultura od prethistorije do suvremenog doba.

Iz ovoga je vidljivo da $\mathrm{BiH}$ nije imala svoj Institut za etnologiju kao posebnu instituciju po ugledu na susjedne republike, ${ }^{15}$ dok je ulogu razvoja etnologije imao već navedeni Zemaljski muzej i njegov etnološki odjel, te muzeji koji su osnovani po većim gradovima (Banja Luka, Zenica, Tuzla, Mostar, ali i Muzej revolucije (Historijski muzej) i Muzej Sarajeva.

Važan faktum u istraživanju povijesti bosanskohercegovačke antropologije predstavlja Kongres evropskih arheologa i antropologa u Sarajevu u augustu 1894. godine. Da bi Austro-Ugarska pokazala cijelom svijetu opravdanost okupacije Bosne i Hercegovine sa carskim potpisom i pečatom, bilo je neophodno formirati naučni centar za istraživanje povijesti zemlje i naroda koji je nastanjuju već dugi niz stoljeća. Osnivanje Zemaljskog muzeja je bio prvi

osnivanja Centra ova istraživanja su se odnosila na periode od neolita pa do 10. vijeka n.e, te u ograničenom obimu i na osmanistiku, dok se od 2008. godine djelokrug istraživanja proširuje i na novija historijska razdoblja. U novoj interdisciplinarnoj koncepciji koja obuhvaća arheologiju, etnologiju, historiju, lingvistiku i antropologiju, a koju je osmislio i realizirao osnivač i dugogodišnji direktor Centra akademik Alojz Benac, ležao je ključ uspjeha ove institucije. Zahvaljujući izuzetnom naučnom i organizatorskom umijeću akademika Benca, te svestranom zalaganju saradnika i članova Centra, ova institucija je postala mjesto okupljanja i djelovanja naučnika sa cijelog Balkana, te šireg evropskog prostora. Zahvaljujući naučnim dostignućima te širokom i svestranom publicističkom djelovanju, Centar za balkanološka ispitivanja je dospio u sam vrh evropskih i svjetskih naučnih tokova. (Opširnije vidjeti: www.anubih.ba)

${ }^{14}$ Godišnjak, kao redovno izdanje Balkanološkog instituta - Centra za balkanološka ispitivanja, izlazi od 1957. godine u kontinuitetu do danas. Svi primjerci su dostupni u Historijskom arhivu Sarajeva.

${ }^{15}$ U bivšoj Jugoslaviji Hrvatska, Srbija, Slovenija i Makedonija su pod drugačijim imenima i u različitim vremenskim intervalima osnivali institute za etnologiju, folkloristiku, etnografiju i antropologiju. 
korak ka tome, a slijedeći je trebao da uz pomoć najboljih evropskih arheologa i antropologa, koji bi ispitivali prošlost Bosne i Hercegovine od prahistorije do kraja 19. stoljeća, baci novo svjetlo na bogatu materijalnu kulturu Bosne i Hercegovine. Ti naučni autoriteti bi na osnovu nalaza dali cjelovit sud o okupaciji kao o civilizacijskoj misiji, koja koristi stručno znanje da bi rekonstruirala bogatu prošlost Bosne i Hercegovine. Zemaljska vlada je organizirala spomenuti Kongres, pokazujući stranim naučnicima dokaze dosadašnjeg djelovanja Vlade i Zajedničkog ministarstva financija u oblasti nauke. ${ }^{16}$

\section{Antropološka Bosna u očima stranih istraživača}

Publiciranjem etnoloških istraživanja kroz spomenute institucije i naučne časopise, njihova referentnost i metodološki aparat, otvarali su i pogled na zapadni Balkan kao i na Bosnu i Hercegovinu "izvana”. Od osamdesetih godina 20. vijeka do danas Bosna i Hercegovina je postala atraktivna destinacija za istraživanja zapadnih stručnjaka, koji su svoja istraživanja, opservacije i tematske članke objavljivali u svjetskim antropološkim i historijskim časopisima.

Bosna i Hercegovina je prije nekoliko decenija zainteresirala inostrane antropologe, jer je bila neotkriveno blago narodnih običaja, usmene tradicije, konfesionalnog i etničkog, urbanog i ruralnog miksa. Od 1992. do danas Bosna i Hercegovina je pored tih specifičnosti posebno područje interesa, pošto se u njoj vodio brutalni agresorski rat vođen izvana, jer je postkonfliktno društvo s visokim međunarodnim utjecajima i nesumnjivo eksperiment svjetskih sila kojega treba antropološki pročitati. To su razlozi koji su ponukali zapadne antropologe da istražuju ovaj geokulturni prostor i dešifruju enigmu zvanu "preživjeli ostaci hiljadugodišnjeg multikulturnog društva u srcu Evrope". ${ }^{17}$

\footnotetext{
${ }^{16}$ Hamdija Kapidžić, "Kongres evropskih arheologa i antropologa u Sarajevu u augustu 1894.", u: Prilozi za proučavanje istorije Sarajeva, Sarajevo: Muzej Grada Sarajeva, 1966, 265-287.

${ }^{17}$ Zapisi o specifičnostima u Bosni i Hercegovini, historijskim prilikama, demografiji, klimi, svakodnevnom životu, religijskim kultovima, ritualima, vjeri, historijskim događajima i drugo, potiču još od putopisaca i diplomatskih emisara, pisaca, uhoda i svih onih koji su imali potrebu
} 
O postratnoj Bosni i Hercegovini, sa svim njenim političkim turbulencijama, kulturnohistorijskim posebnostima i etničkim podjelama, pisali su, između ostalih, i priznati svjetski antropolozi: T. Bringa, ${ }^{18} \mathrm{X}$. Bougarel, A. Gilbert, S. Jansen, William G. Lockwood, F. Markowitz, C. Sorabji, S. E. Wagner, i drugi.

Interesantni drugima, a ne samima sebi - antropološki je apsurd Bosne i Hercegovine. Zašto? Ovaj rad ne istražuje političko-historijski kontekst koji je umnogome odredio marginalizaciju etnologije kao struke u Bosni i Hercegovini u odnosu na susjedne univerzitetske centre (akcentiram Zagreb i Beograd, op.a.), svodeći tako etnološke obrasce na primarno nacionalne i tako "najraznolikiju” zemlju unutar tadašnje socijalističke Jugoslavije postira u pozadinski rang.

Balkanske zemlje su, dirigirane političkim centrima moći, od 1918. do 1992. godine, etnologiju koristile kao "politički opravdano sredstvo" za kulturnu i političku transformaciju. Bosna i Hercegovina je, zbog stalnih promjena društveno-političkih sistema, podvrgnuta nametanju uvijek novih političkih i kulturnih obrazaca, i sa istoka i sa zapada, ostala uskraćena za nacionalni preporod kroz redefiniranje starih identitetskih modela. Ta je historijska paradigma odigrala veliku ulogu u apsurdizaciji ovog fenomena da je Bosna i Hercegovina ustvari bila podložnija propitivanju "izvana” nego "iznutra”. Konsekventno tome, može se reći da je Bosna i Hercegovina antropološki zadržala kontinuitet izučavanja svih oblika života bosanskog čovjeka

da otkrivaju nepoznate zemlje i narode. U 19. i 20. stoljeću bilježi se posebna zainteresiranost francuskih, austrougarskih, njemačkih, engleskih i talijanskih putopisaca za Bosnu i Hercegovinu. Kasnije, nakon 1945. ti se putopisi prevode i koriste u najnovijim antropološkim istraživanjima kao lakmus papir u komparativnoj analizi "nekad i sad". Navest ću samo neka imena: A. F. Giljferding, A. Chaumette des Fossés, A. J. Evans, H. Renner, A. Heimer i mnogi drugi.

${ }^{18}$ Strani antropolozi su napravili neke od najboljih studija i napisali neke od najčitanijih i najvažnijih knjiga o Bosni i Hercegovini. Jedna od takvih je i knjiga "Biti musliman na bosanski način' (Being the Muslim Bosnian Way), autorice Tone Bringa. Ta knjiga je opisala stvarnost jednog "mješovitog" sela u centralnoj Bosni, u kojem su autohtoni mještani katolici i muslimani, odnosno Hrvati i Bošnjaci. Ta studija je razbila stereotipe i teze koji su nastali i promovirali se 1990-tih o tome kako ljudi u Bosni, pripadnici različitih vjera i etnija, ne mogu živjeti zajedno. Njena knjiga je jako uvjerljivo oborila tezu o tzv. "pradavnoj mržnji" (ancient hated thesis). 
kod znatnog broja interesenata koji dolaze iz Evrope i svijeta, ali nije nikad postala nauka od posebnog interesa, jer nije institucionalizirala svoje predmete i metode proučavanja kroz zvanični studij. Stoga je definiranje i etabliranje etnologije i antropologije neophodno, jer će se ovo neistraženo polje koje se uvijek nalazilo negdje "na rubu znanosti" staviti u fokus suvremene misli i metodološke teorije i prakse i dati znanstveni pečat zemlji koja na Balkanu predstavlja kurozitet za kojim tragaju antropolozi po svom naučnoistraživačkom modelu i unutarnjem habitusu.

O proučavanju etnologije u socijalističkoj Bosni i Hercegovini pisala je prof. dr. Larisa Kurtović koja objašnjava aktivnosti etnologa u Bosni kroz to razdoblje, pokazujući puni razmjer do kojeg su etnološki studiji u socijalističkoj Jugoslaviji bili federalni, a ne republički usmjereni cilj.

“Ti su oblici međurepubličkog kruga ideja i ljudi bili posebno snažni u Bosni, gdje je nedostatak institucije na kojoj bi se sticala diploma stvorio ovisnost o univerzitetima u Zagrebu i Beogradu za proizvodnju novog kadra. Takva međurepublička cirkulacija stručnjaka možda je olakšala regionalnu integraciju, ali nije odražavala ili stvarala jednake odnose između etnologa u svim republikama, a nije nužno pomogla i unapređenju etnologije u Bosni i Hercegovini." ${ }^{19}$

Danas, kada je Bosna i Hercegovina međunarodno priznata država, potpuno decentralizirana i entitetski i etnički podijeljena, u jednom je ipak

${ }^{19}$ Larisa Kurtović u svojoj studiji donosi kompletiranu sliku razvoja etnologije u Bosni i Hercegovini od 1945. do 1992. godine, navodeći u kakvom je okruženju nastajala etnologija u Bosni i Hercegovini, pod čijim utjecajima i koliko su bosanskohercegovački znanstvenici doprinosili objektivnom proučavanju etnoloških obrazaca. Ovaj esej u prvom redu izučava načine na koje je odsustvo titularne nacije u socijalističkoj republici Bosni i Hercegovini pružalo etnolozima priliku, da kao istraživači koji su u Bosne i Hercegovine izloženi specifičnim izazovima, od tri istaknute nacije i drugih naroda i narodnosti, koji tu žive do socijalističkog unisonog nacionaltituliranja kroz "bratstvo i jednstvo" i "multikulturalnost”, istaknu stručnu objekciju i meritum. Opširnije: Larisa Kurtović, "Cataloguing Tradition in a Socialist Republic: Ethnology in Bosnia-Herzegovina 1945-1990", in: The Anthropological Field on the Margins of Europe, 1945-1991, Chris Hann and Aleksandar Bošković (eds.) Berlin: Lit Verlag, 2014.

Dostupno na: https://www.academia.edu/7659513/Cataloguing_Tradition_in_a_Socialist_Republic_Ethnology/2014. (pristupljeno: 1. 8.2019) 
jedinstvena: antropologija kao zaseban studij nije ustanovljena ni na jednom bosanskohercegovačkom univerzitetu.

\section{Iz etnologije $u$ antropologiju}

Marginalizacija etnologije na univerzitetima u Bosni i Hercegovini je, ustvari, onemogućila i proces antropologizacije etnologije i njenog institucionaliziranja kao studija, ali i kao znanosti koja se proučava na institutima i dobija pored akademskog i državotvori značaj. Proces njenog daljeg studijskog disciplinarnog etabliranja i nastavnog konstituiranja "riješen je", a zapravo je zaustavljen na jednom nivou: uvođenjem predmeta etnologija i socijalna antropologija na nekoliko fakulteta. ${ }^{20}$

${ }^{20}$ U predgovoru knjige "Kulturna antropologija" prof. dr. Salih Kulenović navodi historijat uvođenja, proučavanja i slušanja ovih predmeta u periodu od 1945. do 1992. godine: "Prije agresije na $\mathrm{RBiH}$ 1992-1995. na bosanskohercegovačkim univerzitetima nije se proučavala kulturna antropologija. Nažalost, vrlo malo se proučavala etnologija kao i socijalna antropologija koje su po svom predmetu proučavanja bliske kulturnoj antropologiji. Etnologija se slušala na geografskom odsjeku Filozofskog fakulteta u Sarajevu kao “b” predmet u periodu 1959-1962. godine, a ukinuta je nakon formiranja Prirodno-matematičkog fakulteta od kada se geografija počela izučavati na tom fakultetu. $U$ to vrijeme ukinut je i Balkanološki institut pri Akademiji nauka i umjetnosti $\mathrm{BiH}$, a istovremeno osnovan pri akademiji nauka u Beogradu. Socijalna antropologija se slušala kao dvosemestralni predmet na Odsjeku za sociologiju Fakulteta političkih nauka u Sarajevu u periodu 1967-1978. godine na trećoj godini studija. Nakon toga umjesto socijalne antropologije počela se predavati etnologija, koja je i danas zastupljena na tom fakultetu. Osnivanjem Filozofskog fakulteta u Tuzli 1994. godine na Odsjeku historije i geografije u nastavni plan i program uvršten je i predmet opšta etnologija, što se i danas proučava. U školskoj 2000/2001. godini u inoviranim planovima na studijskom Odsjeku historije, geografije i žurnalistike Filozofskog fakulteta u Tuzli uveden je i predmet kulturna antropologija." Vidjeti opširnije: Salih Kulenović, Kulturna antropologija, Tuzla: Narodna i univerzitetska biblioteka "Derviš Sušić, 2002, 9-22.

$\mathrm{Na}$ Univerzitetu u Sarajevu danas je predmet etnologija uvršten u nastavni plan i program Prirodno-matematičkog fakulteta na Smjeru turizam i zaštita životne sredine. Na istom fakultetu 1970-ih godina izučavao se predmet antropologija, koji je poslije nekoliko godina preimenovan u bioantropologiju. Na Fakultetu političkih nauka na Odsjeku sociologija kao obavezni predmeti izučavaju se etnologija i uvod u socijalnu antropologijju, dok se u poslijediplomskim studijima izučava socijalna i kulturna antropologija. Na Univerzitetu u Banjoj Luci, na Prirodno-matematičkom fakultetu, Odsjeku za geografiju, izučava se na prvoj godini studija predmet osnovi etnologije. Na Filozofskom fakultetu u Sarajevu od 2015. uveden je na Odsjeku za sociologiju dvopredmetni studij Sociologija i Etnologija. Etnologija se kao predmet sluša i na studijskom odsjeku Bosanski jezik i historija na Pedagoškom fakultetu Univerziteta u Bihaću. 
Čini se da je uspostavljanjem ovih predmeta učinjen prvi korak ka proučavanju ove discipline na naučno-istraživačkom planu, ali i na razvijanju interesa kod studentske populacije za antropološke studije. Međutim, ovaj pristup je dodatno hermetizirao potrebu za širim i ekstenzivnijim proučavanjem raznorodnih tema iz antropološkoga spektruma, jer su i nastavnici i studenti ograničeni brojem predavanja, isključenjem ili nedovoljnim brojem sati provedenih na terenskoj nastavi i praktičnim vježbama, te ispunjavanjem normativa u polaganju ispita.

Kada studentu ne date opciju studiranja određene discipline i svedete tu disciplinu na jedan semestar ili je partikularizirate na više subdisciplina, onda je i njegov interes za određenim studijem sveden na ovu formu ili upotpunosti zaustavljen. Nekolicina onih koji su spoznali da svoju želju za antropologijom mogu ispuniti studiranjem na univerzitetima u inostranstvu, dobiti stipendiju i osigurati materijalnu stabilnost tokom studiranja, odlaze i uglavnom ostaju vani, jer u Bosni i Hercegovini svoje znanje ne mogu pokazati kao profesori na fakultetima, ali i na drugim za antropologe predviđenim radnim mjestima.

$\mathrm{Da}$ bi otvorili pitanje inicijative za pokretanje studija antropologije u Bosni i Hercegovini, zemlji antropologije bez antropologije, na čijoj divergentnoj strukturi stanovništva i konceptu kozmopolitizma i multikulturalnosti, već decenijama pišu, magistriraju i doktoriraju svjetski antropolozi, obratila sam se stručnjacima iz ove oblasti koji godinama pokušavaju da nađu način kako etablirati studij antropologije na nekom od bosanskohercegovačkih univerziteta (dovoljan bi bio Univerzitet u Sarajevu, uzimajući u obzir ukupan broj mladih koji studiraju), kako bi dobili odgovor na pitanje: Koji su razlozi što u Bosni i Hercegovini nije osnovan ovaj studij?

Intervjui su vođeni sa akademikom prof. dr. Rifatom Hadžiselimovićem, ${ }^{21}$

\footnotetext{
${ }^{21}$ Akademik prof. dr. Rifat Hadžiselimović je ugledni bosanskohercegovački bioantropolog, jedan od vodećih bosanskohercegovačkih genetičara i istaknuti profesor na Prirodno-matematičkom fakultetu u Sarajevu. Rifat Hadžiselimović rođen je u Šipragama, Kotor-Varoš, 1944. godine. Od 2013. godine, nakon više od 45 godina radnog staža, izabran je u zvanje emeritusa i djeluje kao znanstveni savjetnik u Institutu za genetičko inženjerstvo i biotehnologiju u Sarajevu. Dopisni član Akademije znanosti i umjetnosti postao je 2018. godine. Magistraturu bioloških znanosti (Antropologija), završio je 1971. godine na Prirodoslovno-matematičkom fakultetu Sveučilišta u Zagrebu, odbranom
} 


\section{prof. dr. Salihom Kulenovićem, ${ }^{22}$ prof. dr. Dželalom Ibrakovićem, ${ }^{23}$}

teze pod naslovom Istorijski aspekt kretanja relativne frekvencije dva alelogena u ljudskim populacijama. Doktorat bioloških nauka završio je 1976. godine na Prirodno-matematičkom fakultetu Univerziteta u Sarajevu, odbranom teze pod naslovom Genetika sekrecije ABH antigena u stanovništvu Bosne i Hercegovine. U razdoblju od 1987. do 2001. bio je na položaju direktora Instituta za genetičko inženjerstvo i biotehnologiju, a od 2001. godine je bio koordinator DNK projekta koji je realiziran u saradnji sa Međunarodnom komisijom za nestale osobe (International Commission on Missing Persons - ICMP) i kao znanstveni savjetnik u Institutu, gdje je od 2006. do 2012. godine djelovao i kao predsjednik Upravnog odbora. Djelovao je kao aktivni član Antropološkog društva Jugoslavije, a osnivač je i član Udruženja genetičara u Bosni i Hercegovini. Dobitnik je prestižnih domaćih i internacionalnih priznanja. Naučne oblasti koje su poseban predmet njegovog proučavanja su: humana genetika, populacijska genetika, bioantropologija i biomedicina, biotehnologija, genotoksikologija, prirodni biološki resursi, i dr. Respektabilan broj originalnih naučnih i stručnih radova, knjiga, članaka, publikacija i udžbenika, te izuzetna citiranost u svjetskoj naučnoj literaturi, pokazatelj je Hadžiselimovićevog izuzetnog doprinosa antropološkoj, genetičkoj i biološkoj znanosti. Danas je naučni savjetnik i spoljni suradnik na Institutu za genetičko inženjerstvo i biotehnologiju u Sarajevu.

${ }^{22}$ Prof. dr. Salih Kulenović je rođen 1944. u Jajcu. Završio je studij geografije sa geologijom na Prirodno-matematičkom fakultetu Univerziteta u Sarajevu 1969. godine. Doktorsku disertaciju pod naslovom Antropogeografske i etnološke odlike Gračanice i okoline odbranio je na Odsjeku za etnologiju Filozofskog fakulteta Univerziteta u Beogradu i stekao akademski stepen doktora etnoloških nauka. U periodu od 1971. do 1991. godine radio je u "Muzeju istočne Bosne Tuzla" kao kustos etnolog, a zatim kao viši kustos i muzejski savjetnik. Na Filozofskom fakultetu Univerziteta u Tuzli izabran je 1993. godine u zvanje docenta za predmet Etnologija, a 1997. godine imao je izbor u zvanje vanrednog profesora za predmet Opšta etnologija. Na Prirodno-matematičkom fakultetu u Tuzli 2003. godine ponovno je izabran u zvanje vanrednog profesora za užu naučnu oblast Antropogeografija. Godine 2007. izabran je u naučno-nastavno zvanje redovnog profesora na užoj naučnoj oblasti Antropogeografija, na Odsjeku za geografiju Prirodno-matematičkog fakulteta Univerziteta u Tuzli, a 2012. godine bira se u počasno zvanje profesor emeritus na Univerzitetu u Tuzli. Od osnivanja Filozofskog fakulteta 1993. godine i Prirodno-matematičkog fakulteta Univerziteta u Tuzli 2002. godine angažiran je u izvođenju nastave uglavnom iz etnoloških i antropogeografskih predmeta. Isto tako, bio je angažiran na dodiplomskom studiju na Prirodno-matematičkom fakultetu Univerziteta u Sarajevu, gdje je izvodio nastavu iz predmeta Geografija naselja i Etnologija. Također, i na Pedagoškom fakultetu Univerziteta u Bihaću gdje je predavao Geografiju i Etnologiju. Dr. Salih Kulenović je bio voditelj postdiplomskog studija na Odsjeku za geografiju Prirodno-matematičkog fakulteta Univerziteta u Tuzli, smjer Stanovništvo i naselja, gdje je izvodio i nastavu. Isto tako, bio je angažiran na postdiplomskom studiju Odsjeka za geografiju Prirodno-matematičkog fakulteta Univerziteta u Sarajevu, smjer Geografske osnove regionalnog i prostornog planiranja, gdje je izvodio nastavu iz predmeta Urbano-geografske osnove regionalnog i prostornog planiranja. Napisao je veliki broj stručnih radova i knjiga iz etnologije, antropogeografije i socijalne antropologije. I, danas, premda je u penziji, predaje na Evropskom fakultetu Kallos u Tuzli.

${ }^{23}$ Prof. dr. Dželal Ibraković je rođen 1954. godine u Ševarlijama kod Doboja. Diplomirao je na Fakultetu političkih nauka Univerziteta u Sarajevu (Odsjek sociologija) 1976. godine. Izabran je u zvanje 


\section{prof. dr. Harizom Halilovićem kao i rektorom Sarajevskog univerziteta prof.} dr. Rifatom Škrijeljem. ${ }^{24}$

\section{Uvaženi profesori Hadžiselimović, Kulenović, Ibraković i Halilović su istakli posebno zadovoljstvo što se kroz ovaj studijski rad postavlja javno pi-}

redovnog profesora 2015. godine. Predaje nastavne discipline: uvod u socijalnu antropologiju, etnologiju, ekološku sigurnost i socijalnu ekologiju na Fakultetu političkih nauka, te sociologiju na Prirodno-matematičkom fakultetu Univerziteta u Sarajevu. Na postdiplomskim i doktorskim studijama Fakulteta političkih nauka predaje nastavne predmete: socijalna i kulturna antropologija porodice i porodica i društvo. U saradničkom angažmanu povremeno predaje i na Filozofskom fakultetu Univerziteta u Tuzli. Objavio je tri autorske knjige te više od 70 naučnih i stručnih radova u različitim naučnim časopisima, zbornicima radova, i sl. U oblasti etnologije objavio je knjige: Bosna, islam - Bošnjaci (2008), kao i BiH na klacakalici etnocentrizma i multilateralnosti (2014) - u izdanju Fakulteta političkih nauka Sarajevo, te Bosanska vizura svijeta (2015) u izdanju Bošnjačke asocijacije 33 Sarajevo. U koutorstvu ima objavljenih više publikacija i udžbenik "Sigurnost demokratskog društva". Član je Odbora za sociološke nauke Akademije nauka i umjetnosti Bosne i Hercegovine. Član je Izdavačkog savjeta Univerziteta u Sarajevu. Rukovodilac je Interdisciplinarnog doktorskog studija Fakulteta političkih nauka Univerziteta u Sarajevu za generaciju 2018/19. školske godine. Aktivno je sudjelovao u radu velikog broja međunarodnih i domaćih naučnih skupova, a bio je nosilac ili učestvovao u realizaciji više naučno-istraživačkih projekata.

${ }^{24}$ Prof. dr. Hariz Halilović je rođen u Srebrenici 1970. godine. Socijalni je antropolog u Centru za globalna istraživanja (Centre for Global Research) na RMIT University u Melbourneu, u Australiji. U fokusu Halilovićevog istraživačkog zanimanja su politički motivirano nasilje, prisilne migracije i translokalni kulturni identiteti. Halilović je autor knjige Places of Pain (Mjesta bola), objavljene u dva izdanja, 2013. i 2015. godine, u nakladi Berghahn Books: Oxford - New York. Ova antropološka studija o posljedicama nasilja na lokalne zajednice u Bosni i Hercegovini nagrađena je na prestižnom svjetskom konkursu. Izdavač Buybook objavio je 2017. godine njegovu knjigu Kako opisati Srebrenicu: Zapisi, eseji, polemike, sjećanja. Halilović je jedan od najcitiranijih znanstvenika iz područja socijalne antropologije u svijetu.

Prof. dr. Rifat Škrijelj je završio studij biologije 1987. godine na Prirodno-matematičkom fakultetu Univerziteta u Sarajevu, magistrirao je 1991. godine na Prirodoslovno-matematičkom fakultetu Sveučilišta u Zagrebu, a doktorat iz oblasti bioloških nauka odbranio je 1995. godine na Prirodnomatematičkom fakultetu Univerziteta u Sarajevu. Akademska karijera prof. dr. Rifata Škrijelja počinje 1987. godine kada je postao asistent pripravnik na Biološkom institutu Univerziteta u Sarajevu i Prirodno-matematičkom fakultetu Univerziteta u Sarajevu. Tokom akademske karijere predavao je na fakultetima i akademijama Univerziteta u Tuzli, Univerziteta u Bihaću, Univerziteta "Džemal Bijedić" u Mostaru i Univerziteta u Sarajevu. Autor je i koautor 52 naučna i stručna rada, 49 kongresnih saopćenja, sedam knjiga, monografija i udžbenika. Funkciju dekana Prirodno-matematičkog fakulteta Univerziteta u Sarajevu obnašao je od 2011. godine, a od 2007. godine bio je član Senata i Etičkog komiteta Univerziteta u Sarajevu. Za rektora Univerziteta u Sarajevu za mandatni period 2016-2020. godine izabran je na sjednici Senata održanoj 12. maja 2016. godine. 
tanje o inicijativi za otvaranje studija antropologije u Bosni i Hercegovini, jer su upravo oni, svaki u svojoj disciplinarnoj oblasti i univerzitetskoj praksi, kreirali šnit prema kojem treba da se nadalje kroji nastavni plan i program i temeljna struktura buduće katedre. Njihov je doprinos višestruko važan: prvo, na polju zalaganja da se uvedu u nastavne curriculume predmeti etnologije, kulturne, socijalne, fizičke i političke antropologije, zatim da se prati svjetski trend $\mathrm{u}$ istraživanju savremenih antropoloških obrazaca, da se takvi koncepti primijene u praksi, ali i zainteresiraju studenti da $\mathrm{u}$ akademskom smislu nastave proučavati socijalne i kulturološke fenomene.

Profesor Salih Kulenović je bio nosilac ovakvih inicijativa posljednjih tridesetak godina. Još od prvih demokratskih parlamentanih izbora u Bosni i Hercegovini, kada se mijenjala društveno-politička struktura i odvijali turbulentni procesi, koje je najsustavnije i najsveobuhvatnije upravo mogla objasniti antropologija, čiji je ključ ispitivanja problematizacija općeprihvaćenih istina i dolaženje do temeljnih saznanja komparativnom analizom.

Prof. Kulenović je u više navrata pokušavao da zajedno sa profesorima, koji su bili na istoj liniji, oformi katedru za etnologiju i antropologiju u Bosni i Hercegovini. Najprije je zajedno sa prof. dr. Ismetom Kasumovićem i prof. dr. Milivojem Rodićem pokrenuo projekat za osnivanje studija etnologije 1991. godine. ${ }^{25}$

“Ta inicijativa je naišla na odobravanje i tadašnje vlasti, koja je formirana nakon prvih višestranačkih izbora u Bosni i Hercegovini . Međutim, tok realizacije ovog studija je prekinuo rat. Istu ideju sam i u toku agresije na Bosnu i Hercegovinu iznio ratnoj Vladi BiH i prof. dr. Rusmiru Mahmutćehajiću koji

\footnotetext{
${ }^{25}$ Prof. dr. Ismet Kasumović (1948-1995) bio je poznati profesor na Fakultetu islamskih nauka, arabista, orijentalista, historičar. Izvanredni intelektualac koji je u svojim znanstvenim radovima napuštao staromodne konzervativne obrasce i istraživanju prilazio holistički, sveobuhvatno i interdisciplinarno. Temeljno se bavio proučavanjem kulturne baštine Bošnjaka na orijentalnim jezicima. Prof. dr. Milivoj O. Rodić (1925-2018) rođen je u Drvaru. Njegova doktorska disertacija "Narodna poezija revolucionarnih epoha kao književni fenomen" sadrži sveobuhvatan prikaz dostupnih izvora, arhivske građe i brojnih radova o ustanku i revoluciji, najprije kao o društveno-političkom fenomenu, a potom kao o književnoj tematici, prvenstveno na prostorima Bosne i Hercegovine.
} 
je tada bio ministar u Vladi, i koji je i kao profesor i istaknuti intelektualac, shvatio značaj ovakvog studija, koji bi etnološki bilježio narodnu tradiciju i kulturu, a zatim je organizirano antropološki propitivao i sistematizirao etnografsku metodu rada. Profesor Mahmutćehajić se složio da je neophodno ustanoviti što prije takav studij kod nas."26

Nakon rata, isti prijedlog uz isto odobravanje i pokretanje prvih koraka ka oformljavanju ovog studija, prof. Kulenović je izložio i ministru kulture u Vladi FBiH g. Fahrudinu Rizvanbegoviću da se taj studij osnuje u Sarajevu na Filozofskom fakultetu. ${ }^{27}$ Dok se procedure oko uspostavljanja studija ne dovrše, prof. Kulenović je iznio prijedlog tadašnjem dekanu Filozofskog fakulteta u Sarajevu prof. dr. Ibrahimu Tepiću i akademiku Muhamedu Filipoviću, ${ }^{28}$ tadašnjem šefu Odsjeka za filozofiju, da se predmeti etnologija i antropologija uvrste na Odsjek za filozofiju Filozofskog fakulteta u Sarajevu, koji su prijedlog i prihvatili. Međutim, do realiziranja nikad nije došlo. Niti su ovi predmeti uvedeni na ovaj odsjek, niti je ikad finalizirana realizacija osnivanja katedre za etnologiju i antropologiju.

\footnotetext{
${ }^{26}$ Intervju sa Salihom Kulenovićem (Univerzitet u Tuzli, lični intervju, 19. 8. 2019)

Akademik Rusmir Mahmutćehajić je rođen u Stocu 1948. godine. Doktorirao je elektrotehniku, a postdoktorske studije je završio na Katoličkom univerzitetu u Leuvenu, Belgija. Istaknuti je univerzitetski profesor, bosanskohercegovački intelektualac, erudita i polithistor. Od 1997. godine je predsjednik Međunarodnog foruma Bosna. U užem naučnom području objavio je preko stotinu stručnih i naučnih radova od kojih osam knjiga. Objavio je i sedamnaest knjiga autorske proze, političkih i filozofskih eseja, te prijevoda na bosanski jezik.

${ }^{27}$ Prof. dr. Fahrudin Rizvanbegović je umirovljeni redovni profesor na Odsjeku za književnosti naroda Bosne i Hercegovine Filozofskog fakulteta Univerziteta u Sarajevu i bivši ministar obrazovanja, nauke, kulture i sporta u Vladi Federacije Bosne i Hercegovine. Rizvanbegović je autor više znanatvenih djela iz bošnjačke usmene i pismene književne tradicije.

${ }^{28}$ Prof. dr. Ibrahim Tepić (1947-1997) je bio univerzitetski profesor, doktor historijskih nauka. Bio je šef Odsjeka za historiju, predsjednik Društva istoričara Bosne i Hercegovine i sekretar redakcije Godišnjaka Društva istoričara Bosne i Hercegovine. Bio je dekan Filozofskog fakulteta u Sarajevu u periodu 1994-1997.

Akademik Muhamed Filipović (1929-2020), doktor je filozofskih znanosti, istaknuti bh. intelektualac, filozofski pisac, teoretičar i esejist. Bio je protagonist političkih promjena u Bosni i Hercegovini za vrijeme raspada Jugoslavije i izvanredni znalac suvremene filozofske misli. Također, bio je član ANUBiH i predsjednik BANU (Bošnjačke akademije nauka i umjetnosti).
} 
Na Odsjeku za sociologiju Filozofskog fakulteta u Sarajevu danas postoji dvopredmetni studij sociologije i etnologije, dok se na Odsjeku za arheologiju koji je uspostavljen 2008. godine studenti mogu upoznati sa predmetima osnovi etnologije i fizička antropologija. Sve predmete koji su zasnovani na etnološkoj matrici na Odsjeku za sociologiju vodi i predaje isti profesor. ${ }^{29}$

To govori o deficitarnosti stručnog kadra i za etnologiju, koja je ipak od 1945. do danas kontinuirano prisutna kao predmet proučavanja na određenim studijskim grupama i kao muzejsko odjeljenje i/ili zbirka u određenim muzejskim institucijama u Bosni i Hercegovini. Manjkavost stručnog kadra je posebno uočljiva danas kada je, nakon disolucije SFRJ i stjecanja nezavisnosti, Bosna i Hercegovina trebala izobrazovati kadrove na svojim univerzitetima, ali zbog odsustva jasno determiniranih stavova o pitanju potrebe za izučavanjem ove nauke, nije otvoren studij ni etnologije, a ni antropologije u širem smislu koju je neophodno što prije i formalizirati.

"Budući da je različitost (difference) toliko rijetka i golema tema u poslijeratnoj Bosni i Hercegovini, vrijeme je da se definira koji su to zapravo mjerodavni kriteriji da se nešto zove antropologijom. Stasanje nove generacije studenata zainteresirane za antropološku literaturu, principe i metodologije ključan je aspekt definiranja ovih parametara i početak procesa etabliranja zvanične antropologije. U idealnom slučaju, neki od tih studenata mogli bi se stipendirati za doktorski studij iz antropologije van Bosne i Hercegovine, $\mathrm{u}$ cilju izgradnje kadra za buduću katedru." ${ }^{30}$

\footnotetext{
${ }^{29} \mathrm{Na}$ Odsjeku za sociologiju Filozofskog fakulteta u Sarajevu od 2015. godine postoji dvopredmetni studij Sociologija i etnologija. U okviru prvog ciklusa studenti polažu slijedeće predmete koji su disciplinarno vezani uz etnologiju: Etnologija bh. društva, Etnologija u BiH do 1945, Uvod u etnomuzikologiju, Etnologija Balkana, Uvod u folkloristiku. Sve predmete predaje doc. dr. Aiša Softić. Izašla je prva generacija diplomanata i MA studija, tako da odnedavno na ovom Odsjeku vježbe drži Tatjana Žarković, MA. Nadati se da će se mladi kadrovi specijalizirati u etnološkim disciplinama i popuniti ovaj evidentno prazan akademski prostor. Nažalost, na ovom dvopredmetnom studiju nije ustanovljen predmet antropologija.

${ }^{30}$ L. Kurtović, "Etnografski eksperimenti", 376.
} 
Prof. dr. Larisa Kurtović koja je doktorirala antropologiju na Univerzitetu Berkley u Kaliforniji jedna je od bosanskohercegovačkih mladih i već afirmiranih antropologa koji su stekli znanje i zvanje van Bosne i Hercegovine ${ }^{31}$ Pored prof. Kurtović i već spomenutog prof. dr. Hariza Halilovića, antropologijom se znanstveno bavi i prof. dr. Azra Hromadžić, koja je nakon završene srednje škole dobila stipendiju i iz rodnog Bihaća otišla na studij kulturne antropologije, koji je završila na Univerzitetu u Pennsylvaniji, Philadephia, gdje je magistrirala i doktorirala. Danas je asistentica na Odsjeku za antropologiju Univerziteta u Syrakuzi. ${ }^{32}$

$\mathrm{Na}$ polju znanstveno-istraživačkoga djelovanja iz kulturne antropologije u Sjedinjenim Državama zapaženo je još jedno bosanskohrcegovačko ime - Larisa Jašarević, koja težište svoga antropološkoga interesiranja stavlja na popularnu medicinu, metafiziku prirode i komparaciju socijalnog sa prirodnim i kulturnim u postratnim društvima kao što je i država iz koje dolaze Bosna i Hercegovina. ${ }^{33}$ Ovi uspješni, afirmirani i ugledni mladi

${ }^{31}$ Larisa Kurtović je asistentica na Odsjeku za sociologiju i antropologiju Fakulteta društvenih nauka na Univerzitetu Ottawa u Kanadi. U opisu svoga djelovanja, Kurtović navodi da je politički antropolog koji provodi istraživanje aktivističke politike, postsocijalističke transformacije i posljedica međunarodne intervencije u poslijeratnoj Bosni. Njeno šire interesovanje uključuje postsocijalističke studije, političku estetiku, humor, performanse i performativnost, historijsku antropologiju i etnologiju, sekularnu politiku i političku ekonomiju.

${ }^{32}$ Azra Hromadžić je kulturna antropologinja s istraživačkim interesima za antropologiju međunarodne politike u kontekstu stvaranja države u poslijeratnoj Bosni i Hercegovini. Njena knjiga Citizens of an Empty Nation: Youth and State-making in Postwar Bosnia and Herzegovina (University of Pennsylvania Press) predstavlja etnografsko istraživanje međunarodno usmjerene politike poslijeratne intervencije u Bosni i Hercegovini i odgovor lokalnog stanovništva, posebno mladih, na te napore politike. Knjiga je prevedena na srpski jezik: Samo Bosne nema: Mladi i građenje države u poslijeratnoj Bosni i Hercegovini, Beograd: Biblioteka XX vek, 2017.

${ }^{33}$ Larisa Jašarević je antropologinja i predaje u programu Globalnih studija na Univerzitetu u Chicagu. Njeno posljednje istraživanje odnosi se na ljekovitost pčela u Bosni i izvan nje, a zajedno povezuje ekologiju, islamsku metafiziku prirode i eshatologiju. Godine 2017. objavila je izuzetno prihvaćenu i citiranu knjigu iz kulturne antropologije pod nazivom Helth and Welth on the Bosnian Market: Intimate Dept provodeći etnografsko istraživanje o stanovništvu Tuzle nakon rata koji su u duhovnom i materijalnom škripcu, potpuno podređeni pravilima modernog potrošačkog tržišta. Jašarević prati obične Bosance u potrazi za liječenjem - od upotrebe medicinskih lijekova do alternativnih lijekova i narodnih iscjelitelja raznih vrsta. Pitanja finansijskog blagostanja, potraga za dobrim životom i tradicionalni okvir mentaliteta kad je u pitanju kultura jela, sigurnosti 
antropolozi svoj interes za bavljenjem ovom strukom uspješno ostvaruju na prestižnim univerzitetima zapadnih razvijenih društava, koji su još u 19. stoljeću jasno determinirali metodološke ciljeve antropološke nauke i najbolji su parametar za dva zaključka: prvi, da individualni interes postoji i da je zatomljen i neistaknut kod pojedinaca, jer se antropologija ne nalazi na "univerzitetskoj trpezi" - dakle, nije ponuđena kao opcija. ${ }^{34} \mathrm{I}$, drugi, da će ovi istaknuti znanstvenici karijeru nastaviti veoma uspješno graditi tematizirajući procese u suvremenoj historiji u Bosni i Hercegovini, a da neće biti u prilici svoje znanje podijeliti na (ne)ustanovljenoj katedri za antropologiju u Bosni i Hercegovini. I, kada bi ova inicijativa urodila plodom za nekoliko godina, ovi doktoranti iz antropologije mogli bi biti "gostujuća" podrška (dragocjena), dok se ne izeduciraju i formiraju stručni kadrovi, koji bi na svojim željama i ambicijama konstituirali ovu nauku i uveli je u sfere akademskog, društvenog i institucionalnog djelovanja.

Prof. dr. Dželal Ibraković se kao profesor socijalne antropologije u svome dugogodišnjem radu na katedri za sociologiju Fakulteta političkih nauka u Sarajevu istinski zalagao za ustanovljenje studija antropologije i pokušavao da kroz svoj predmet unaprijedi interes kod studenata za proučavanje ove znanosti o čovjeku.

Ibraković smatra da se u bosanskohercegovačkom univerzitetskom establišmentu vodi filozofski diskurs o imenovanju ove nauke, a ne o neophodnosti njenog etabliranja, čime bi se antropološke misli i ideje konceptualizirale i između ostalog i znanstveno rasvijetlili pokušaji da se nacionalni idiomi stave u pogrešan instrumentalizirajući kontekst. ${ }^{35}$

i ličnog zadovoljstva - našle su mjesto u ovoj zanimljivoj antropološkoj studiji.

${ }^{34}$ Ovogodišnji podaci pokazuju da je studij Antropologije u Zagrebu najtraženiji dvopredmetni studij u Republici Hrvatskoj s otprilike 15 kandidata prijavljenih na 1 dostupno upisno mjesto. Vidjeti: http://www.mojfaks.com/postani-student/navala-na-filozofski-ove-godine-vise-brucosa-a-posebno-je-bila-borba-za-jedan-studij.

${ }^{35} \mathrm{Na}$ pitanje: Postoji li volja da se osnuje katedra za antropologiju koja bi mogla osposobiti stručnjake neophodne u svim sferama bh. društva?, prof. dr. Dželal Ibraković tvrdi da je antropologija/ etnologija u potrazi za imenom. 
"Naravno, kod nas je bolje voditi raspravu o tome kako se zove nauka nego se posvetiti njenom utemeljenju i razvoju, izradi curriculuma, saradnji fakulteta, prevazilaženju surevnjivosti." ${ }^{36}$

Prof. dr. Hariz Halilović svoju univerzitetsku karijeru uspješno gradi u Melbourneu i Los Angelesu i učesnik je na referentnim znanstvenim konferencijama, seminarima i okruglim stolovima iz suvremene socioantropologije. Njegove studije i publikacije dale su svojevrsni doprinos, kako razumijevanju Bosne tako i saznavanju u Bosni izvan Bosne. Njegova knjiga Places of Pain (Mjesta bola), koja je do sada objavljena jedino na engleskom, 2014. godine proglašena je najboljom knjigom iz antropologije objavljene 2013. u Americi. To je veoma prestižna nagrada i zove se The Prose Awards a donosi sintetička istraživanja o Bosni i ljudima iz Bosne u dijaspori: u Australiji, Americi i Švedskoj. Ova knjiga se koristi kao antropološka literatura na pedesetak univerziteta u svijetu, što samo po sebi govori o kakvom se važnom i vrijednom djelu iz struke radi. Danas postoji već obimna antropološka literatura o Bosni u većini ozbiljnih univerzitetskih biblioteka u svijetu. Ta literatura se neprestano povećava, međutim, to naučno znanje nije dovoljno poznato i priznato u samoj Bosni i Hercegovini. Da bi osvijetlili put ove znanosti u suvremenoj Bosni i Hercegovini, a istovremeno pružili objektivnu sliku zasnovanu na empiriji i praksi iz internacionalnog akademskog rakursa, profesor Halilović se "nametnuo" kao prava adresa za intervju o statusu antropologije u Bosni i Hercegovini, te potrebi otvaranja ovog studija. ${ }^{37}$

S obzirom na komplesknost antropologije, zahtjevnost metodologije i neophodnu eruditivnost i širinu duha koju antropolog istraživač treba posjedovati da bi mogao seriozno prići predmetu istraživanja, prvo pitanje prof. Haliloviću i bilo je otkud interes za antropologiju i da li on pripada redu onih Bosanaca koji su željeli studirati antropologiju u Bosni i Hercegovini, ali to nisu mogli iz navedenih razloga pa su sami krenuli za svojim željama i inhibicijama i nauku pronašli van granica svoje države.

\footnotetext{
${ }^{36}$ Intervju sa Dželalom Ibrakovićem (Fakultet političkih nauka Sarajevo, lični intervju, 22. 8. 2019)

${ }^{37}$ Intervju sa Harizom Halilovićem (RMIT University Melbourne, Australija, lični intervju, 8. 9. 2019)
} 
"Antropologiju sam otkrio kroz svoj studij na filozofskom fakultetu u Melbournu, nakon što sam migrirao u Australiju 1998. godine. Da je takva disciplina postojala u Bosni, sigurno bi me privukla, jer su me oduvijek zanimale kulture i način na koji ljudi žive i kreiraju i održavaju svoje identitete. Međutim, kada sam postao migrant u Australiji, ta senzibilnost ili zainteresiranost za različite načine života kojima različite zajednice žive je postala i dio moje svakodnevnice. Naime, našao sam se u gradu i zemlji koja je bila jedan mozaik kultura, jezika, načina života: od raznih migrantskih zajednica iz Azije, Afrike, Evrope, Pacifika do dominantne anglosaksonske kulture i prilično marginalizirane domorodačke, odnosno starosjedilačke, kulture australskih Aboridžana. Sami Aboridžani, kako ih mi nazivamo, ustvari su niz različitih naroda koji su živjeli u Australiji oko 40.000 godina prije dolaska i kolonizacije Evropljana. Svi ti narodi imaju svoja imena, kao npr. Kulin narod, Vurundžeri, Kuri i drugi, koji žive ili su živjeli na području današnjeg Melbournea i države Viktorija. Dakle, kao friški imigrant, osjetio sam jaku potrebu da saznam što više o svim tim različitim ljudima, njihovim kulturama, načinu života... Ta zainteresiranost za ove teme je vremenom postala moje zanimanje, moj profesionalni identitet, postao sam antropolog. Uradio sam dodiplomske i postdiplomske studije, te doktorirao u oblasti antropologije na prestižnom University of Melbourne (najbolje rangirani univerzitet u Australiji, a ove godine na 32. mjestu na listi najboljih univerziteta u svijetu)." 38

Iz Halilovićevog odgovora može se iščitati da pripada generaciji koju je u najvažnijim formativnim godinama, ranim dvadesetim, kada se trebalo odlučivati u kojem pravcu nastaviti školovanje i šta odabrati za svoju primarnu struku, zadesila ratna stvarnost, a agresija zločinačke vojske protjerala uz masovno krvoproliće i genocid iz rodnih domova. S obzirom da ga je životna krivulja odvela u Australiju, tu je, integrirajući se u heterogeno australsko društvo, dobio priliku da se educira u smjeru koji je želio i u svojoj zemlji, ali to nije mogao iz najmanje dva razloga: prvo, takav studij ne postoji u Bosni i Hercegovini i, drugo, da je i postojao, on zbog brutalne agresije i svog mukotrpnog migrantskog puta ne bi bio u mogućnosti pristupiti Sarajevskom univerzitetu.

\footnotetext{
${ }^{38}$ Intervju sa Halilovićem.
} 
Ovaj odgovor je i svojevrsna afirmacija i konfirmacija tezi da se kod svake studentske generacije izdvoji određeni broj kod kojeg prevlada želja da dobiju poduku iz etnologije i antropologije, nadasve kao znanosti o kulturi.

Kao dugogodišnji predavači na bosanskohercegovačkim univerzitetima, profesori Kulenović i Ibraković su u svakodnevno direktnoj živoj komunikaciji sa studentima, stoga su u mogućnosti odrediti da li oni smatraju da bi im proučavanje ove nauke otvorilo put razumijevanju svoga sociokulturnog identiteta i proširilo aspekte gledanja na različite globalne fenomene? Kulenović je mišljenja da su studenti uvijek spremni da ove predmete izučavaju kroz nastavni proces i da ih izučavaju onoliko koliko je potrebno za dobru ocjenu, te da se njihov interes tu zaustavlja, jer oni koji žele nisu u prilici dobiti više znanja. Rijetki su oni koji imaju "srce" da nastave studirati vani ili ostanu ovdje i u okviru postojećih studija stječu više naučne stepene i tako kroz studijske članke, eseje, knjige i druge publikacije intenziviraju kod šire javnosti interes za uspostavljanje i studija antropologije.

"Nekoliko mojih studenata je magistriralo i doktoriralo na antropološkim temama, bili su mi asistenti na predmetima etnologija, opšta etnologija i antropogeografija na Tuzlanskom univerzitetu, ja sam im bio mentor i recenzent njihovih stručnih djela, ali nisam primijetio njihovu zainteresiranost da ovi predmeti prerastu u studij. Zbog nepoduzetnosti i nedostatka stručnog kadra, mi smo ostali i bez predmeta etnologija na Prirodno-matematičkom fakultetu u Tuzli." ${ }^{39}$

Ibraković navodi da je njegova osobna impresija kao predavača na predmetima socijalna antropologija i etnologija da nedostaje koordinacija od najviših do najnižih univerzitetskih instanci, pa se stječe dojam kako i unaprijeđenje nastavnog procesa zavisi od pojedinačnih napora. Ne vodi se računa ni o potencijalnim saradnjama, gostovanjima ili razmjeni predavača, zajedničkim projektima, a posebno što u toj "parcijalizaciji” pameti i resursa nema niti dogovora oko zajedničkog pristupa, razradi syllabusa predmeta, usaglašavanja sa osnovnim evropskim i svjetskim pravcima,

\footnotetext{
${ }^{39}$ Intervju sa Kulenovićem.
} 
uspostavljanja članstva u naučnim asocijacijama iz ove oblasti, kao ni oko školovanja i usmjeravanja kadra koji bi se bavio ovim pitanjima. ${ }^{40}$

Na Odsjeku sociologija Fakulteta političkih nauka u Sarajevu, o cilju i sadržaju predmeta etnologija se kaže da je neophodno "usvojiti analitički pristup i proširena znanja iz oblasti etnologije i razumjeti sve važne aspekte kompleksne i široke problematike usko vezane za lokalnu i globalnu scenu na kojoj se smjenjuju raznovrsni socio-kulturološki procesi i pojave inherentni dvjema međusobno uslovljenim objektivnim stvarnostima - tradiciji i modernizmu; Kritički analizirati aktualna dešavanja unutar savremenog društva, kulturološke tokove, te ulogu pojedinca i etnosa sagledavajući mogućnosti prepoznavanja i zaštite tradicijskih vrijednosti i znanja; Samostalno prosuđivati na temelju usvojenih znanja iz discipline i ovladati vještinom njihove primjene na bosanskohercegovačku zbilju uz lični angažman". ${ }^{41}$ Osnovne tematske jedinice koje prate nastavni proces su: "Nastanak i razvoj naučne discipline etnologije i pojmovne kontoverze: etnologija i/ili socijalna i kulturna antropologija".

Na pitanje kako učiniti atraktivnim upis na antropološke studije, Ibraković odgovara neposrednim uvidom u interese potonjih studentskih generacija, smatrajući da je to moguće učiniti u jednoj generaciji, ali će ona onda biti suočena sa zidom nepriznavanja diplome, jer se izmjene zakona i pravilnika teško odvijaju radi blokade političkog života koji je opeterećen sa ANP, UZP, EU, VE, stalnom pričom o ratu i pravdi-nepravdi, te raznim drugim skraćenicama koje skraćuju pamet i prosto guraju mlade ljude vani.

"Dakle, smatram da postoji potreba, ali sam realista koji nije za to da se otvaraju skupi studijski programi, a da se ne pokaže zainteresovanost mladih ljudi kojima se na svakom koraku nudi siguran posao vani, a poseban je problem što za takvu vrstu studija mi nemamo ni dovoljno stručnog kadra koji se specijalizirao samo u ovoj oblasti." ${ }^{42}$

\footnotetext{
${ }^{40}$ Intervju sa Ibrakovićem.

${ }^{41}$ Vidjeti: file:///C:/Users/Korisnik/Downloads/MA-ETNOLOGIJA.pdf (pristupljeno: 11. 8. 2019)

${ }^{42}$ Isto.
} 
Ibraković posebno naglašava trenutno stanje u društvenim i humanističkim naukama gdje je prisutno "svaštarenje", a to se prenosi i na druge oblasti gdje recimo predmete etnologija i etnologija Bosne i Hercegovine popunjavaju sa "postojećim kadrovima" iz potpuno drugih oblasti, a koji su u usmjerenju "blizu" tim oblastima. Nadalje Ibraković potencira veliki broj tema iz socijalne antropologije koje nameće bosanskohercegovačka kontroverzna i apsurdna svakodnevica, a kojima se u naučno-istraživačkom smislu, s aspekta struke, može itekako doprinijeti rasvjetljavanju, analizi i pronalasku adekvatnog rješenja. Naprimjer, istraživanje jednoroditeljskih porodica (in vivo), posebno onih koji su u ratu izgubili jednog ili oba roditelja, pitanje postratnog sindroma i kod učesnika rata i onih koji su rođeni poslije, migrantska i unutarnja i vanjska kriza, umiranje sela, dislocirana Bosna širom svijeta, mržnja na društvenim mrežama, ukidanje bosanske pripadnosti kao objedinjavajućeg bosanskohercegovačkog faktora, kako su Bosanci i Hercegovici naučeni i kako se uče da mrze drugog i drugačijeg, kako ostvarivati društvenu terapiju, djelovanje sekti, terensko istraživanje selefijskih zajednica, (de)militarizacija bosanskohercegovačkog društva, korupcija kao tradicijski elemenat, savremene i tradicijske spolne neravnopravnosti, veličanje "snalažljivosti” i negativni junaci, Bosna i Hercegovina na društvenim mreŽama, prodaja tradicije, brendiranje tradicije, itd. ${ }^{43}$

Nabrojane teme pokazuju realnu potrebu za osnivanjem katedre za antropologiju, međutim, posljednjih dvadeset godina takva inicijativa nije pokrenuta ni sa jednog fakulteta, odsjeka kao ni predmetnog nastavnika ili neke druge instance.

\section{Institucionaliziranje antropologije: osnivanje katedre za antropologiju Univerziteta u Sarajevu}

Da bi se testirala volja za osnivanjem katedre za antropologiju, najprije bi trebalo pokrenuti inicijativu. Univerzitet u Sarajevu ${ }^{44}$ kao udružena

\footnotetext{
${ }^{43}$ Intervju sa Ibrakovićem.

${ }^{44} \mathrm{O}$ osnivanju Univerziteta u Sarajevu opštinije vijeti: https://www.unsa.ba/o-univerzitetu/organi-
} 
zajednica svih visokoškolskih ustanova Kantona Sarajevo funkcionira tek od početka 2019. godine, a do sada su sve odluke o katedrama donosile na pojedinačnim fakultetima.

"Dakle, realno je očekivati da u skorije vrijeme neće doći do formiranja usmjerenja antropolog drugog i trećeg ciklusa (bilo da je riječ o socijalnom, kulturnom ili socijalnokulturnom antropologu) kada je riječ o društvenim i humanističkim naukama, a vjerovatno ni o biološkom (fizičkom) antropologu, jer to podrazumijeva interdisciplinarni studij novog profila. A, nakon toga i zakonodavne promjene nomenklature zanimanja, priznavanja diploma, njihovo uvrštavanje u opća akta svih institucija i usaglašavanje, te primjena u praksi, dug je i zahtjevan proces. Premda je prošlo dosta vremena od uvođenja bolonjskog procesa i danas se kaska za prepoznavanjem prvog i drugog stepena školovanja na fakultetima u zakonskom smislu. To su sve otežavajuće okolnosti koje će i dalje pitanje anthroposa (čovjeka) tretirati tako kao da odgovor zna "svako". A, čim je svako - može i odrednica niko!" 45

Profesor Halilović koji na najkonstruktivniji način predstavlja bosanskohercegovačku antropologiju u inozemstvu, na svjetskim kongresima ove discipline, ističe da su zemlje Balkana, posebno Hrvatska i Srbija,

zacija/historija (pristupljeno: 18. 7. 2019)

Univerzitet u Sarajevu je velika i složena organizacija u čijoj misiji je da kroz nastavu i istraživanje educira kvalitetne, sposobne, kreativne i međunarodno kompetentne kadrove u svim oblastima od interesa za Bosnu i Hercegovinu, koji će profesionalno i kvalitetno izvršavati zahtjevne zadatke moderne privrede u evropskom i svjetskom političkom, ekonomskom, društvenom i kulturološkom okruženju. Opredjeljenje Univerziteta je da bude autonomna akademska zajednica nastavnika-istraživača, umjetnika i studenata, inkorporirana u međunarodnu univerzitetsku i akademsku zajednicu. Organizacija i djelatnost Univerziteta u Sarajevu, kao javne visokoškolske ustanove u Kantonu Sarajevo, propisani su Okvirnim zakonom o visokom obrazovanju Bosne i Hercegovine, Zakonom o visokom obrazovanju Kantona Sarajevo i Statutom Univerziteta. Univerzitet u Sarajevu čini dvadeset i pet Organizacija i djelatnost Univerziteta u Sarajevu, kao javne visokoškolske ustanove u Kantonu Sarajevo, propisani su Okvirnim zakonom o visokom obrazovanju Bosne i Hercegovine, Zakonom o visokom obrazovanju Kantona Sarajevo i Statutom Univerziteta. Univerzitet u Sarajevu čini dvadeset i pet fakulteta i akademija i pet instituta, punopravnih članica Univerziteta, interno organiziranih unutar šest vijeća grupacija nauka/umjetnosti iz područja: društvenih, humanističkih, medicinskih, tehničkih, prirodno-matematičkih i biotehničkih i umjetnosti.

${ }^{45}$ Intervju sa Ibrakovićem. 
institucionalizirale ovu nauku, dajući joj pored akademskog i državotvorni značaj.

"Ja imam suradnju s kolegama antropolozima iz Srbije i Hrvatske, pogotovo s kolegama Odjela za etnologiju i antropologiju Sveučilišta u Zagrebu i Zadru. U Zadru mentoriram i jednog doktoranta i član sam mentorskog vijeća Sveučilišta u Zadru. U Hrvatskoj izučavanje antropologije ne zaostaje iza evropskih univerziteta. Neki od velikih antropoloških kongresa su se upravo održali posljednjih godina u Hrvatskoj, tj. u Zagrebu i Zadru. Bio sam razočaran što na tim kongresima jedino nije bilo Bosne i Hercegovine, ali je bilo Bosanaca: pored mene iz Australije, tu je bila i kolegica Senka Božić Vrbančić (rodom iz Konjica) sa Sveučilišta u Zagrebu i Mario Katić (rodom iz Odžaka) koji predaje na Sveučilištu u Zadru." ${ }^{46}$

Bosna i Hercegovina iz nekih nedovoljno artikuliranih i racionalno neobjašnjivih razloga idalje "tapka u mjestu”. Koliko nas u tome sprječava nacionalna nedozrelost i hektičnost u osmišljavanju univerzitetskih platformi za sutrašnjicu? Da li zato što ovo komplicirano državno uređenje, koje je u cijelosti decentralizirano po etničkoj i entitetskoj osnovi, ne nudi nikakav jedinstven univerzalan okvir djelovanja. Pitala sam profesora Halilovića da li ima ideju (na osnovu iskustava u organizaciji ove znanosti u Australiji) kako institucionalizirati etnologiju i antropologiju na bosanskohercegovačkim univerzitetima i da li na neformiranje ove katedre kod nas utječu gorespomenuti politički razlozi?

"Zasigurno da postoje politički razlozi zašto antropologija kao zasebna nauka nikad nije zaživjela u Bosni, iako Bosna i Hercegovina ima puno više razloga i predispozicija da napravi kvalitetan studij antropologije nego neke susjedne zemlje. Naime, Bosna, odnosno različite teme vezane za nju, su bile predmetom niza antropoloških studija, a desetine antropologa iz raznih zemalja se aktivno bavi izučavanjem Bosne i pisanjem o Bosni. Pored toga, ja osobno poznajem oko 20 kolega antropologa porijeklom iz Bosne i Hercegovine, koji su profesori i istraživači na raznim univerzitetima diljem svijeta.

\footnotetext{
${ }^{46}$ Intervju sa Halilovićem.
} 
Mnogi od nas, odnosno većina nas, aktivno se bavimo istraživanjem tema vezanih za Bosnu, kako u Bosni i Hercegovini tako i u dijaspori. Od 2007. dovodim svoje studente antropologije iz Australije na studijska putovanja u Bosnu i Hercegovinu. Mnogi od mojih studenata, uključujući i PhD studente su radili svoje istraživačke projekte i disertacije na temu Bosne i u Bosni. Sav taj potencijal se vrlo lako može iskoristiti za uspostavljanje i konsolidiranje odjela antropologije na UNSA. Dakle, postoji antropološko znanje o Bosni, postoje antropolozi, a sigurno da postoji i dovoljno studenata koji bi se zainteresirali za antropologiju; samo izgleda da ne postoji politička volja za tako nešto. Ja sam više puta ove teme načinjao i o njima razgovarao s dekanima i rektorima UNSA, uključujući i sadašnjeg rektora prof. Škrijelja, koji je izrazio spremnost podržati osnivanje studija antropologije na UNSA. Nadam se da će za vrijeme svog mandata uspjeti ovaj prijedlog pokrenuti s mrtve tačke. Naravno, spreman sam ponuditi svo svoje iskustvo iz Australije i Amerike (gostujući sam profesor na UCLA) u kreiranju jednog modernog i po svjetskim stnadardima utemeljenog studija antropologije u BiH, ukoliko se moja ekspertiza bude tražila, odnosno bude prihvaćena, jer je već nudim." ${ }^{47}$

Da li Bosni i Hercegovini - zemlji antropologije bez antropologije uistinu treba antropolog - onaj koji objašnjava suvremene procese i uspoređuje ih sa drugim u istom vremenu ili sa sličnim u prošlosti? Da li nama, naprimjer, treba dobar sudski vještak u sporovima koji znače kulturološko (ne)razumijevanje na Balkanu, ili da li će istraživati suptilne veze multikulturalnosti i sinkretizacije običaja, istraživanje prolaznih migranata i onih koji će tek doći preko procesa demografskog pražnjenja Bosne i Hercegovine, istraživati suptilnost dijaspore, prisilne i one dobrovoljne, radne ili političke? Da li se u Bosni i Hercegovini traži znanje stručnjaka za lokalne etnografske studije, za narodne običaje, njihovu vezu sa savremenošću, ali i meritoran tumač kulturnog i historijskog konteksta? Da su nam antropolozi potrebni - mi bismo ih i imali. Nemamo ih, jer u javnosti preovladava mišljenje da to može "svako" ${ }^{48}$

${ }^{47}$ Isto.

${ }^{48}$ Prof. Ibraković nadalje ističe komponentu banaliziranja znanja u recentnoj bosanskohercegovačkoj medijskoj i općoj javnosti naglašavajući da taj termin "to svako može" u osnovi predstavlja 
Stasanje nove generacije studenata zainteresirane za antropološku literaturu, principe i metodologiju ključan je aspekt definiranja ovih parametara i početak procesa etabliranja zvanične antropologije. U idealnom slučaju, neki od tih studenata mogli bi se stipendirati za doktorski studij iz antropologije van Bosne i Hercegovine u cilju izgradnje kadra za buduću katedru. Finansijska podrška za takvu vrstu programa može se tražiti i saradnjom s pojedinačnim univerzitetima, vladama, ali i antropološkim fondacijama poput Wenner-Grena, koji podržava razvoj antropologije širom svijeta. ${ }^{49}$

Antropologija i antropolozi, uglavnom oni koji dolaze iz zapadnih zemalja, moderno govoreći globtrotteri - oni koji vide, osluškuju i ćute najzanimljivija mjesta i ljude na Planeti, u svojim objavljenim istraživanjima o Bosni i Hercegovini ističu da je njena posebnost upravo u paradoksalnosti. Sve što postoji u svijetu, postoji i u Bosni i Hercegovini. Ali, ono što ima u Bosni i Hercegovini nema u cijelom svijetu. Dok svjetski antropolozi naglašavaju u svojim studijama atraktivnost i intrigantnost Bosne i Hercegovine u odnosu na sve zemlje regiona, i u širem evropskom kontekstu, dotle se bosanskohercegovačko javno mnijenje bombardira u medijskom prostoru nedovoljno istraženim i nekritičkim teorijama o antropološkim temama sa nekompetentnim zaključcima, te raznim pseudoantropološkim i kvazietnografskim tekstovima, diskutabilnim interpretacijama na koje nema stručne reakcije. Nedostatak struke, odnosno, višedecenijsko zatvaranje očiju pred ovakvim kontraproduktivnim pojavama mogu naštetiti akademskoj zajednici, društvenoj klimi, ali i eksternoj slici koju svaka loša, iskrivljena ili maliciozna (re)interpretacija može dezavuirati.

negaciju znanja i potiranje struke. Antropologija kao sveobuhvatno znanje o čovjeku i međuljudskim odnosima, koja ekstenzivno i multidisciplinarno tretira fenomene, u najvećoj je opasnosti od ovakvog "banaliziranja" i svođenja na "struku koju može svako raditi".

Također, Andrej Vidović u tekstu "Antropologija: Civilizacijski Gordijev čvor” zaključuje da će se u budućnosti antropologija sve više boriti sa provizornim mišljenjima da je ona "nauka koja generalizira”, premda je riječ o empirijskoj znanosti, koja ne treba da se bori za legitiman status jedne od humanističkih znanosti. S druge strane, preovladavaju tenzije podjela na antropologiju koja se orijentira na historijske fenomene kulture i društva i onu koja je u traganju za "vanvremenim, nepromjenjivim strukturama i obrascima".

${ }^{49}$ L. Kurtović, "Etnografski eksperimenti", 376. 
"Antropološki koncepti kao što su kultura, etnicitet ili narod nevjerovatno su lako zloupotrebljivi u poslijeratnoj Bosni i Hercegovini, jer se zapravo jako dobro uklapaju u esencijalne teze, iz kojih su se, da ironija bude veća, prvobitno izrodile." ${ }^{50}$

Institucionaliziranje antropologije kao studija na najvećem i najreferentnijem univerzitetu u Bosni i Hercegovini, Univerzitetu u Sarajevu, još nije počela u strukturalno-organizacijskom okviru, jer nije zvanično takav zahtjev do sada poslan glavnim tijelima Univerziteta (Rektorat, Senat, Upravni odbor). Zahtjev uz obrazloženje može doći samo od pripadajućeg fakulteta koji je članica Univerziteta u Sarajevu, tj. od organizacijskih jedinica UNSA, a koji se razmatra na sjednici Senata. Fakultet kao centralni okvir svih studija jednu takvu proaktivnu inicijativu može dobiti od svog nastavnog kadra, pojedinačno ili kolektivno, pripadajućih studijskih grupa kao i komplementarnih odjeljenja i studenata. Prema dostupnim podacima, studij se može osnovati na Prirodno-matematičkom fakultetu ili Filozofskom fakultetu ili između dvije ili više organizacijske fakultetske jedinice na Univerzitetu u Sarajevu. Studij može biti prvog, drugog i trećeg ciklusa ili integrirani trostupanjski, koji obuhvata sve studijske stupnje od diplome do doktorata.

Rektor Škrijelj smatra da bi konjukturno bilo da ovakav studij bude formiran kao paralelni iza kojeg bi stajale dvije univerzitetske ustanove - Univerzitet u Sarajevu i neki od svjetskih najutjecajnijih univerziteta na kojima se proučava antropologija i prate suvremeni stručni i znanstveno kredibilni trendovi, kako bi studenti dobili obje međunarodno priznate diplome. Pored toga, korisno bi bilo i to što bi došlo do svojevrsne interaktivne razmjene kadrova, mišljenja i novih metodoloških tendencija u struci. ${ }^{51}$

Škrijelj podržava ideju o inicijativi za ustanovljenje katedre za antropologiju, podvlačeći važnost studija od domena genetike i bioantropologije do društvenog i kulturnog sagledavanja različitih fenomena u Bosni i Hercegovini i svijetu. Mišljenja je da je potrebno napraviti prvi korak -

\footnotetext{
${ }^{50}$ Isto, 377.

${ }^{51}$ Intervju sa Rifatom Škrijeljem (Rektorat UNSA, lični intervju, 11. 9. 2019)
} 
razgovarati sa najznačajnijim bioantropologom u Bosni i Hercegovini akademikom prof. dr. Rifatom Hadžiselimovićem, koji bi s aspekta i znanosti i iskustva mogao ocijeniti mogućnosti za pokretanje studija antropologije i u slučaju procjene da postoji interes i kreirati program studiranja, predmete koji bi se izučavali, modele rada i stjecanja univerzitetskih stručnih zvanja.

Nakon meritorne i ozbiljne procjene o potrebi otvaranja katedre za antropologiju, kada bi Rektorat Univerziteta u Sarajevu dobio argumentiranu analizu i finaliziran detaljan studijski program sa izloženom inicijativom, koju potpisuje akademik Rifat Hadžiselimović, ovaj zahtjev bi bio stavljen u proceduru za saglasnost svih mjerodavnih tijela Univerziteta u Sarajevu. Iz ovoga se može zaključiti da je prava adresa za kreiranje programske paradigme buduće katedre upravo istaknuti akademik prof. dr. Rifat Hadžiselimović, koji je u svojoj vrlo cijenjenoj profesorskoj i znanstveno-istraživačkoj karijeri bio inicijator progresivnih naučnih aktivnosti i voditelj zapaženih i visokorangiranih naučnih programa.

Na pitanje da li biste Vi bili spremni da udete u ovakav jedan kompleksan proces kao što je otvaranje studija antropologije na Univerzitetu u Sarajevu, jer uvaženi rektor prof. dr. Rifat Škrijelj smatra da samo Vi možete biti voditelj inicijative sobzirom na Vašu kompetenciju, referentnost, znanje i autoritet?, profesor Hadžiselimović dao je slijedeći odgovor:

"Zavisno od koncepta budućeg studija (odsjeka), siguran sam da se katedra može locirati na UNSA. Za početak treba osnovati inicijativnu grupu. Ako odlučite, možete računati na moju podršku i pomoć." ${ }^{52}$

Sudeći prema dosadašnjoj praksi, univerzitetska zajednica u Bosni i Hercegovini (ni)je nadomak ostvarenju cilja koji se zove otvaranje katedre za antropologiju na nekom od univerziteta u Bosni i Hercegovini. U razgovoru sa univerzitetskim profesorima u Bosni i Hercegovini i u inozemstvu, stječe se dojam da postoji volja za konstruiranjem antropoloških obrazaca na budućoj katedri za antropologiju ili etnologiju i antropologiju, kako bi se studij mogao zvati. Također, intervjuirani su istakli svoju bezrezervnu ${ }^{52}$ Intervju sa Hadžiselimovićem. 
podršku koja bi se temeljila na stručnom znanju, ljudskim resursima, konkretnom iskustvu i praksi kao i vremenu kao najvažnijem resursu, kako bi ustanovili moderan studij prema svjetskim standardima.

Ne nedostaje nam stručnjaka, ne nedostaje ni volje - samo još ono malo da oformimo inicijativnu grupu koja će izraditi stručni program studija, postupiti po procedurama, i čekati ono "da", i tu smo pred vratima katedre za antropologiju. Do tada ćemo idalje biti među rijetkim državama na Balkanu u kojoj se na univerzitetima ne proučava antropologija. I, da, do tada ćemo idalje živjeti još jedan paradoks.

\section{Zaključak}

Bosna i Hercegovina je zemlja čija je povijest, kultura, tradicija i mentalitet stanovništva prepoznata "iz vana", u pogledu stranih antropologa, međutim, paradoks leži u tome da bosanskohercegovačka akademska zajednica nije pružila adekvatan odgovor "iznutra".

Zemlje jugoistočne Evrope Slovenija, Hrvatska, Srbija, Crna Gora i Sjeverna Makedonija, u različitim vremenskim periodima i pod različitim sociokulturnim uvjetima svoje su prve susrete sa antropološkom naukom imale početkom 20. stoljeća, a fundamentalni institucionalni okvir za njeno izučavanje formiran je u periodu SFRJ. Danas se antropologija kao samostalna studijska jedinica proučava na univerzitetima u Ljubljani, Zagrebu, Beogradu i Skoplju.

S Bosnom i Hercegovinom, međutim, stvari stoje potpuno drugačije. Dok su države Regije institucionalizirale ovu nauku, dajući joj pored akademskog i državotvorni značaj, ovdje još uvijek nema dovoljno intelektualne snage i sistemske strategije da se kroz univerzitetska tijela osnuje ovaj studij.

Iz razgovora koji su vođeni sa bosanskohercegovačkim istaknutim profesorima u Bosni i Hercegovini i u inostranstvu, kao i aktualnim rektorom Univerziteta u Sarajevu, stječe se dojam da zbog etatističko-birokratskih proceduralnosti i izraženog subjektiviteta u procesu odlučivanja, inicijative 
za pokretanje samostalnog studija antropologije neće doći od onih koji na to imaju zakonsko pravo (fakulteti, katedre, nastavni kadar, studenti), jer da bi takve inicijative prošle dalje univerzitetske procedure neophodno je kreirati plan, istražiti kapacitete, provesti anketiranje, etc. S druge strane, postoji bojazan kod onih koji odlučuju o tome, da bi se bosanskohercegovačku antropologiju moglo ideologizirati kroz političku prizmu, i prozvati je "bošnjačkom" jer su srpski i hrvatski nacion kroz akademski sistem u Srbiji i Hrvatskoj konstituirali matricu za antropološko proučavanje vlastitih etnosa. Tako Bosna i Hercegovina, zemlja antropologije, ostaje bez antropologije.

Gledajući kroz povijesnu prizmu, drvo antropologije od svih regionalnoh centara prvo je zasađeno u Sarajevu koje je bilo domaćin najvećeg međunarodnog skupa svjetskih antropologa. Kongres evropskih arheologa i antropologa održan je u augustu 1894. godine, što je stavilo fokus stranih istraživača na Bosnu i Hercegovinu čiju je kulturu trebalo približiti, objasniti i otkriti Austro-Ugarskoj nakon okupacije kao i drugim interesentima za dešifriranje nepoznatih kultura Evrope i Balkana.

Zemaljski muzej (1888) kao najstarija naučno-istraživačka institucija na Balkanu i Balkanološki institut koji je iz nje proizišao (1904), uveliko su doprinijeli da Sarajevo postane važno izvorište novih istraživačkih ideja i interdisciplinarnih projekata etnološkog, etnografskog, arheološkog, povijesnog, lingvističkog, filozofskog i sociološkog spektra djelovanja.

Poslije Drugog svjetskog rata kulturna antropologija u Bosni i Hercegovini se razvija preko etnološko-etnografskih obrazaca i kroz institucije koje su u opisu svoga znanstvenog djelovanja očuvale tradiciju izučavanja i zastupanja etnologije.

Ipak, može se reći da je Bosna i Hercegovina imala prvog magistra antropologije 1972. godine, koji je bio tada jedini magistar u bivšoj Jugoslaviji. Riječ je o akademiku prof. dr. Rifatu Hadžiselimoviću, koji je magistrirao na Sveučilištu u Zagrebu, a predavao je antropologiju na Prirodno-matematičkom fakultetu u Sarajevu. 
Od osamdesetih godina 20. vijeka do danas Bosna i Hercegovina je postala atraktivna destinacija za istraživanja zapadnih stručnjaka, koji su svoja gledišta, opservacije i tematske članke objavljivali u svjetskim antropološkim i historijskim časopisima.

"Vanjskom pogledu” neće još neko vrijeme biti pridružen "unutrašnji pogled”. Institucionalizacija antropologije čeka neke druge ljude, neko novo vrijeme i neku državotvorniju politiku.

\section{IZVORI I LITERATURA}

\section{Knjige}

Bringa, Tone, Biti musliman na bosanski način, Sarajevo: Dani, 1997.

Gerc, Kliford, Antropolog kao pisac, Beograd: Biblioteka XX vek, 2010.

Hadžiselimović, Rifat, Uvod u teoriju antropogeneze, Sarajevo: Svjetlost, 1986.

Halilović, Hariz, Places of Pain. Forced Displacement, Popular Memory and Trans-local Identities in Bosnian War-Torn Communities, New York: Berghahn Books, 2013.

Ibraković, Dželal, Na klackalici etnocentrizma i multilateralnosti (Paradigma $\mathrm{BiH})$, Sarajevo: Fakultet političkih nauka, 2014.

Kulenović, Salih, Etnologija sjeveroistočne Bosne, Tuzla: Muzej istočne Bosne, 1995.

Kulenović, Salih, Kulturna antropologija (uvod u kulturnu antropologiju i izbor tekstova),Tuzla: Narodna i univerzitetska biblioteka "Derviš Sušić", 2002.

Žmegač Čapo, Jasna, Gulin Zrnić, Valentina, Šantek, Goran Pavel (ur.), Etnologija bliskoga, Zagreb: Naklada Jesenski i Turk, 2006. 


\section{Članci}

Čapo-Žmegač, Jasna, "Etnologija ili (socio)kulturna antropologija", u: Studia ethnologica Croatica, Zagreb: SEC, 1993, 11-25.

Govedarica, Blagoje, "Pedeset godina Centra za balkanološka ispitivanja Akademije nauka i umjetnosti Bosne i Hercegovine", u: Međunarodna naučna konferencija "Balkanologija danas" u povodu 50-godišnjice Centra za balkanološka ispitivanja ANUBiH, Godišnjak, knjiga 42, Sarajevo: ANUBiH, 2013, 9- 22.

Kapidžić, Hamdija, "Kongres evropskih arheologa i antropologa u Sarajevu u augustu 1894", u: Prilozi za proučavanje istorije Sarajeva, Sarajevo: MGS, 1966, 265-289.

Kulenović, Salih, "Uvod u kulturnu antropologiju”, u: Kulturna antropologija, Tuzla: Naučna i univerzitetska biblioteka "Derviš Sušić”, 2002, 9-22.

Kurtović, Larisa, "Cataloguing Tradition in a Socialist Republic: Ethnology in Bosnia-Herzegovina 1945-1990", in: The Anthropological Field on the Margins of Europe, 1945-1991, Chris Hann and Aleksandar Bošković (eds.) Berlin: Lit Verlag, 2014, 305-339.

Kurtović, Larisa. "Etnografski eksperimenti: Manifest za podršku razvoja društvenokulturne antropologije u Bosni i Hercegovini i kratak pregled studentskih radova”, u: Godišnjak Fakulteta političkih nauka, Sarajevo: FPN, 2010/2011, 359-390.

\section{Ostali izvori}

https://www.academia.edu/7659513/Cataloguing_Tradition_in_a_Socialist_Republic_Ethnology/2014. (pristupljeno: 1.8.2019) http://www.anubih.ba/index.php/bs/?option=com_content\&view=article\& id=245\&Itemid=698\&lang=ba (pristupljeno: 17 . 7. 2019) http://www.arhivsa.ba/wordpress/?page_id=1782. (pristupljeno: 1.7 .2019 ) https://www.unsa.ba/o-univerzitetu/organizacija/historija (pristupljeno: 18. 9. 2019) http://www.mojfaks.com/postani-student/navala-na-filozofski-ove-godine- 
vise-brucosa-a-posebno-je-bila-borba-za-jedan-studij. (pristupljeno: 30. 8. 2020)

file://C:/Users/Korisnik/Downloads/MA-ETNOLOGIJA.pdf (pristupljeno: 11. 8. 2019)

https:/etno.ffzg.unizg.hr/wp-content/uploads/2012/11/Doktorski-program-etnologije-i-kulturne-antropologije-za-web_4-4-2017.pdf (pristupljeno: 15. 9. 2020)

https://frenzyspark.com/2012/12/30/antropologija-civilizacijski-gordijevcvor (pristupljeno: 30. 5. 2019)

https://www.academia.edu/7659513/Cataloguing_Tradition_in_a_Socia-

list_Republic_Ethnology/2014. (pristupljeno: 1. 8. 2019)

http://scindeks.ceon.rs/article.aspx?artid=1820-79361045017V (pristupljeno: 15.7 .2020$)$

https://www.zemaljskimuzej.ba/bs/etnologija (pristupljeno: 14. 6. 2019)

\section{Predavanja i intervjui}

Ibraković, Dželal, “Uvod u socijalnu antropologiju” (predavanja), Sarajevo: Odsjek Sociologija, FPN, 2018.

Intervju sa Hadžiselimović, Rifatom. Institut za genetičko inženjerstvo i biotehnologiju. Lični intervju, 12.9. 2019.

Intervju sa Halilović, Harizom. RMIT University Melbourne, Australija. Lični intervju, 8. 9. 2019.

Intervju sa Ibraković, Dželalom. Fakultet političkih nauka. Lični intervju, 22. 8. 2019.

Intervju sa Kulenović, Salihom. Univerzitet u Tuzli. Lični intervju, 19. 8. 2019. Intervju sa Škrijelj, Rifatom. Rektorat Univerziteta u Sarajevu. Lični intervju, 11. 9. 2019. 


\title{
BOSNIA AND HERZEGOVINA BETWEEN REGIONAL AND WORLD ANTHROPOLOGY AS A HOSTAGE OF ETATIST-BUREAUCRATIC PROCEDURAL
}

\begin{abstract}
Summary
Bosnia and Herzegovina is a country whose history, culture, tradition and mentality of the population are recognized "from the outside", in terms of foreign anthropologists, however, the paradox lies in the fact that the Bosnian academic community did not provide an adequate response "from the inside". The countries of Southeast Europe Slovenia, Croatia, Serbia, Montenegro and Northern Macedonia, in different time periods and under different sociocultural conditions had their first encounters with anthropological science at the beginning of the 20th century, and the fundamental institutional framework for its study was formed in SFRY. Today, anthropology as an independent study unit is studied at the universities of Ljubljana, Zagreb, Belgrade and Skopje.

With Bosnia and Herzegovina, however, things are completely different. While the states of the Region have institutionalized this science, giving it in addition to academic, a state-building significance, there is still not enough intellectual strength and systemic strategy here to establish this study through university bodies.

Interviews with prominent professors in Bosnia and Herzegovina and abroad, as well as the current rector of the University of Sarajevo, give the impression that due to etatist-bureaucratic procedures and pronounced subjectivity in the decision-making process, initiatives to start an independent study of anthropology will not come from those who have the legal right to do so (faculties, departments, teaching staff, students), because in order for such initiatives to pass further university procedures, it is necessary to create a plan, research capacities, conduct surveys, etc. On the other hand, there is a fear among those who decide on it, that Bosnian
\end{abstract}


anthropology could be ideologized through a political prism, and called "Bosniak" because the Serbian and Croatian nations have constituted a matrix for anthropological study of their own ethnic groups through the academic system in Serbia and Croatia. Thus, Bosnia and Herzegovina, the country of anthropology, remains without anthropology.

Looking through a historical prism, the tree of anthropology of all regional centers was first planted in Sarajevo, which hosted the world's largest international gathering of anthropologists. The Congress of European Archaeologists and Anthropologists was held in August 1894, which focused foreign researchers on Bosnia and Herzegovina, whose culture was to be brought closer, explained and discovered to AustroHungary after the occupation, as well as to other interested parties in deciphering unknown cultures in Europe and the Balkans.

The National Museum (1888) as the oldest scientific research institution in the Balkans and the Balkan Institute that emerged from it (1904), greatly contributed to Sarajevo becoming an important source of new research ideas and interdisciplinary projects of ethnological, ethnographic, archaeological, historical, linguistic, philosophical and sociological spectrum of activity.

After the Second World War, cultural anthropology in Bosnia and Herzegovina developed through ethnological-ethnographic patterns and through institutions that have preserved the tradition of studying and representing ethnology in the description of their scientific activities.

Nevertheless, it can be said that Bosnia and Herzegovina had its first master's degree in anthropology in 1972, which was then the only master's degree in the former Yugoslavia. Academician prof. dr. Rifat Hadžiselimović, who has a master's degree from the University of Zagreb, and taught anthropology at the Faculty of Science in Sarajevo. From the 1980s until today, Bosnia and Herzegovina has become an attractive destination for research by Western experts, who have published their views, observations and thematic articles in world anthropological and historical journals. For 
a while, the "outside" view will not be accompanied by the "inside" view. The institutionalization of anthropology awaits some other people, some new time and some more state-building policy. 